Article

\title{
New Public Institutional Forms and Social Innovation in Urban Governance: Insights from the "Mayor's Office of New Urban Mechanics" (MONUM) in Boston
}

\author{
Carmelina Bevilacqua *(D), Yapeng Ou, Pasquale Pizzimenti and Guglielmo Minervino \\ CludsLab PAU Department, Mediterranea University of Reggio Calabria, 89124 Reggio Calabria, Italy; \\ yapeng.ou@unirc.it (Y.O.); pasquale.pizzimenti@unirc.it (P.P.); guglielmo.minervino@unirc.it (G.M.) \\ * Correspondence: cbevilac@unirc.it
}

Received: 30 September 2019; Accepted: 12 December 2019; Published: 18 December 2019

\begin{abstract}
This paper investigates how public sector institutions change their form and approach to achieve a socially innovative urban governance. The "Mayor's Office of New Urban Mechanics" (MONUM) in Boston, Massachusetts (USA) proves a representative case of innovation in the public sector. As a new type of government agency, it is essentially an open innovation lab dedicated to innovative evidence-based policymaking. Following a new dynamic organizational pattern in urban governance, MONUM is conducive to project-oriented social innovation practices and horizontal multi-sectoral collaboration among the three societal sectors: public, private, and civil. Its results suggest that first, the peculiarity of MONUM lies in its hybrid and boundary-blurring nature. Second, new institutional forms that experiment with urban governance can rely on multi-sectoral collaboration. Third, MONUM has experimented with a systemic approach to social innovation following the "design thinking theory." The MONUM case can contribute to the current debate in Europe on the need to harmonize EU policies for an effective social inclusion by promoting the application of the place-sensitive approach.
\end{abstract}

Keywords: urban governance; new public institutional forms; multi-sectoral collaboration; social innovation; MONUM

\section{Introduction}

The innovation gap in the private sector is a subject of study that has raised much interest over the last 15 years [1-9]. Meanwhile, at a local scale, the public sector starts showing a growing interest in addressing the issue of urban governance. Public institutions are increasingly considered as important for driving systemic innovation and local development [10,11], which, as facilitators of social cooperation, can concretize social aspirations into realities and promote civil and political participation. Indeed, recent research has demonstrated that weak institutions, in general, and poor-quality government, in particular, constitute a crucial obstacle to development [12]. This has opened a broad research path concerning the relationship between public institutions and social innovation [13-17]. Social innovation can be spurred by new institutional forms, including experimental activities, largely relying on greater involvement of all stakeholders [18-20].

Since the 1990s, socio-economic changes affected social policies in "re-drawing the boundaries of social citizenships" and "giving a more prominent role to cities" [21] (p. 302). Murray and others [22] clarified that social innovation manifests in boundary-blurring activities developed through the interaction of the three conventional spheres of society: the public, the private, and civil society. The linkage among these sectors has created space for the formation of new dynamic organizational 
patterns of urban governance underpinned by people-centered "design thinking" [23] and participatory methods enhanced by Information and Communication Technologies (ICTs) [24-26]. Such a process is driven by a horizontal multi-sectoral collaboration among actors (Figure 1a) that responds to specific socio-economic issues with socially innovative practices [19]. Lemke [27] and Swyngedouw [28] consider multi-sectoral collaboration as a new form of governmentality. Actors from the three societal sectors have to interact (Figure 1b) within a "fuzzy area," namely, an "institutional void" of unclear rules and norms, and incomplete information and ambiguous knowledge [29,30]. Such practices, often characterized by blurred boundaries between public and private initiatives, result in flexible governmental forms [31] wherein actors can occasionally assume different roles. This flexibility is critical to provide positive contributions to innovation [32-34].
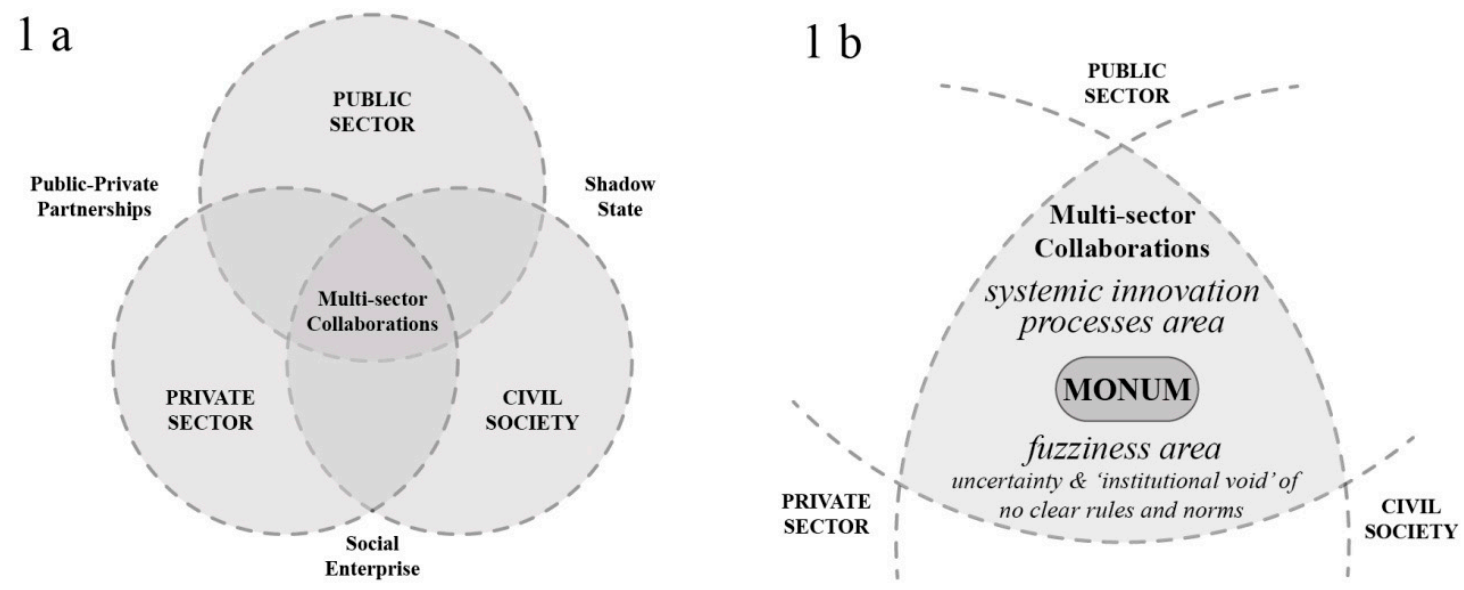

Figure 1. (a) New dynamic organizational pattern in urban governance; (b) Fuzziness emerges from multi-sectoral collaboration patterns. MONUM: "Mayor's Office of New Urban Mechanics." (Source: Drawing by the authors after Nicholls and Murdock [19]).

In line with the objectives of the Cohesion Policy, social innovation is widely promoted by the European Union [35]. According to the EU, social innovation is a main driver of socio-economic development, in that it is "highly focused on meeting social needs by enhancing social interactions and integrating ideas, knowledge and vision of civil society with urban development" [36] (p. 110). It is acknowledged that cities have a key role to play in driving social innovation at the local level. This is because that they are drivers of technological development, economic growth, and citizen empowerment to collaboratively mobilize locally embedded tangible and intangible assets [36]. Since 2011, the EU has stressed the importance for cities to adopt a different organizational paradigm based on seven principles: (1) holistic approach; (2) long-term strategic planning; (3) foresight and vision-building; (4) community involvement; (5) collective mobilization; (6) long-term objectives; and (7) inter-city partnerships and co-operation [36]. To drive a more social innovation-oriented development, cities need to (1) mobilize tangible and intangible resources; (2) adopt new organizational forms and urban governance models; and (3) promote multi-sectoral interactions and multi-stakeholder partnerships.

In this regard, this paper is aimed to explore how innovative public organizational paradigms can lead to social innovation at the local level. Specifically, it provides an analytical outline of the innovative project-oriented public organizational paradigm designed to implement a more effective approach to delivering tailored public services based on citizens' actual needs through social innovation initiatives. It proposes the Boston-based (Massachusetts, USA) "Mayor's Office of New Urban Mechanics" (MONUM) as a representative explanatory case of innovation in the public sector, following a new dynamic organizational pattern in urban governance. Such a pattern is conducive to project-oriented social innovation practices and horizontal collaboration among the three societal sectors (Figure 1b). Similar initiatives have been observed in other cities in the USA and Europe, which have established relationships and exchange with MONUM. 
The paper first conducts a critical review of the literature on social innovation from the public administration perspective, considering that cities need a more effective urban governance to address complex socio-economic and environmental challenges. Then, the MONUM case is investigated with a qualitative approach according to the eight characteristics of innovation in public government elaborated by Borins $[7,8]$. It is analyzed as a single exploratory case study using primary and secondary data to identify its main operational elements. The discussion section carries out a preliminary comparative analysis between the findings of MONUM and two cases selected by the EU as best practices of social innovation in 2015 [35]. Synthetically, this analysis reveals their main similarities and differences with the aim to gain a broad understanding of the urban governance approaches to social innovation practices between the USA and EU. Finally, the paper suggests new research trajectories to better address this topic, especially concerning the post-2020 European Union's Cohesion Policy. The topic explored may be relevant for the current European debate on leveraging cities' potential of place-based innovation by promoting inclusive multi-sectoral interactions, multi-stakeholder governance and strategic investment [36]. Lessons learnt from the MONUM case can provide useful references to the current need to harmonize EU policies to effectively reduce socio-economic inequalities by shifting towards a place-sensitive approach [12].

The study, by presenting the analysis of the MONUM case together with the preliminary comparison with the two EU best practices, offers a possible framework to structure the change factors that public organizations address concerning social innovation rationale. This framework intends to guide further analysis of the soundness of this change in terms of social benefits for local communities. The output of the latter activity may result in the definition of likely measurable indicators of social innovation-oriented policies (in terms of effects/impacts) to test and evaluate the transferability of the lessons learnt to European cities.

\section{Social Innovation in Public Administration}

Neoliberalism [37], in antithesis to the antecedent Fordist-Keynesian consensus [38], shifted economic power away from manufacturing to financial institutions [39]. This reduced the state to a mere organizer and protector of an institutional framework characterized by strong private property rights, free markets and free trade [40]. Truly, the changing territorial dimension at which social policies are designed and implemented, together with the horizontal involvement of increased and variegated actors, has led to a vertical decentralization of regulatory powers [21]. In this globalized context, two parallel phenomena occurred in cities. First, the role of cities and their governance morphed into a market-enterprise model [41,42]. The subsequent need of achieving competitive advantages led to the adoption of business management principles, concepts and tools [43,44]. Second, since the beginning of the 21st century, an increasing number of people have committed to active innovation processes of development and social well-being through shared networks and agendas [20,45]. Originally, these are grassroots initiatives aimed to produce solutions through atypical combinations of people, ideas and tools by mobilizing resources and knowledge around local issues [46-48]. Among others, Fressoli [49] argues that the encounter of innovative grassroots organizations with public and private institutions can lead to the development of new models of inclusion and knowledge production.

According to Brandsen and others [50], it is better to conceptualize rather than define social innovation as a complex societal process. Social innovation is therefore referred to as all activities, created mainly by networks and joint action in social realms beyond business and government routines, at any given moment, to raise the hope and expectations of progress towards something "better" (a more socially sustainable/democratic/effective society). Social innovation, as a participatory process and related outcome, is believed to be able to support progress and lead to the improvement of the urban system [51,52]. Common improvements may include products, services, procedures, policies, design and models that simultaneously meet social needs and create new collaborative relationships [22,53-56]. The horizontal relationship-based approach to problem-solving is prone to generate effective, efficient, 
and sustainable solutions [25]. However, the link between social innovation and organizational forms should be an empirical question, not a presupposition [50].

Innovation in the public sector aims at creating shared value [17,57], thereby achieving not only a more effective economic yield [6], but more democratic and just results, such as responsiveness, legitimacy and legality [58]. A fundamental aspect of innovation within the public sector refers to the "logic of appropriateness," meaning the care for local specificities [59]. Community responsiveness to this kind of innovation largely depends on if: (1) innovation is legitimate and politically sustainable [57]; (2) it refers to democratic, shared, and relevant values such as accessibility, participation, empowerment, transparency, accountability, and equality [17]; and (3) its results address citizens' needs [60].

Social innovation requires a systemic approach. This is because that socio-economic issues as it addresses cannot be perceived as isolated; rather, they must be considered within a "system" showing the inter-dependence between their own subsystems and the broader external ecosystem [61]. This explains why social model-based programs tend to fail to remedy complex socio-economic problems [62]. Indeed, without an overall strategy, they have isolated the areas under intervention from their adjacent economy and social context. A systemic approach is critical to create a good social innovation environment, as it can create, by promoting "systems thinking" and interactions among societal sectors, opportunities for co-creation of shared social values [63]. Besides, such an approach is conducive to multi-sectoral collaboration, which is most likely to trigger large-scale social change rather than isolated intervention by individual organizations [64]. In this sense, coupling public, private and civil institutions and local communities is critical to drive social innovation [65].

The City of Boston is leading and fostering a social innovation ecosystem [66,67] while embracing an experimental challenge. Its new urban governance mechanism led by the public administration addresses cross-cutting socio-economic issues through a horizontal collaborative approach involving all the three societal sectors. Such a mechanism enables the public administration to actively engage the civil society and meanwhile, effectively play its intermediation role in the direction of the private sector. MONUM operates exactly as an interface between the public and private sectors and civil society where the opportunity for experimenting and capturing social innovation is higher $[19,20,22]$.

\section{Research Method}

The paper is aimed to explore how innovative public organizational paradigms can lead to social innovation at the local level. Specifically, it provides an analytical outline of the MONUM innovative project-oriented public organizational paradigm. In pursuing this objective, the research (Figure 2) follows a qualitative approach. Primary data were collected by four in-person interviews and by attending MONUM public presentations. Secondary data were collected by examining official public documents, the MONUM website, and online videos about MONUM and its project.

The literature review sets the ground for framing the case study analysis, highlighting the relationship between social innovation and public institutions. The desk analysis of the MONUM website, published projects [68] and video documents [69-72] facilitated an initial description of the case. It also provided a basis for preparing semi-structured interviews focused on MONUM's role within Boston's public administration, institutional structure, and methodology to operate. Two semi-structured interviews were conducted with key Office members, plus one with another member retrieved from an online article [73], as well as an additional interview with an external MONUM collaborator. The latter allowed for the comparison with the information obtained from internal sources. Lastly, a public consultation meeting was also attended to gain first-hand information on the implementation of MONUM projects. 


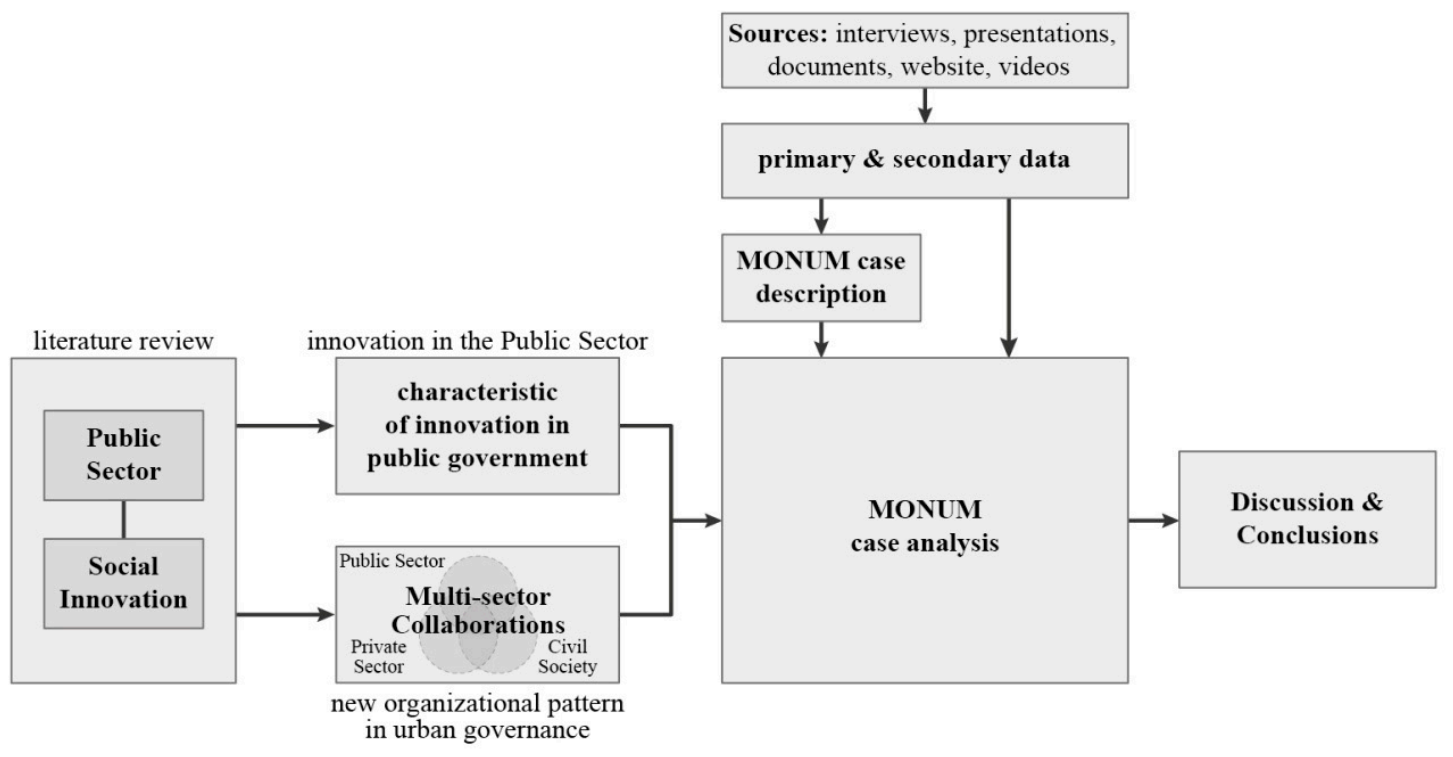

Figure 2. Map of the Methodology (Source: Drawing by the authors).

The explanatory case study analysis is based on primary and secondary data. The main sources are: semi-structured interviews, official documents, and online data on the MONUM initiatives and projects. The case study analysis is aimed to, rather than outlining a model to be transferred and replicated in EU context, point out the key aspects related to governance that can serve as useful references for triggering social innovation in EU lagging cities/regions. The investigation sheds light on the relevance of social innovation mechanisms led by the public administration for addressing local socio-economic problems. This is done mainly by conceptualizing and operationalizing an inclusive and integrated form of urban governance that promotes the collaboration among actors from public and private sectors and civil society. The MONUM case is argued as an improved urban governance pattern led by public institutions that respond better to the emerging socio-economic challenges by spurring social innovation with the horizontal collaboration amongst the three societal sectors.

The MONUM case is analyzed according to the eight characteristics of innovation in public governments elaborated by Borins $[7,8]$, namely organizational change in the public sector, process improvement, collaboration within the government, external collaboration, citizen empowerment, information technology, use of market incentives, and use of volunteers. The following is a brief description of each characteristic retrieved from Borins' works $[7,8,24,74]$ (Table 1). His work analyzed the changes in the innovation in the American public sector since the early 1990s and found three significant points: (1) a major increase in inter-organizational collaboration; (2) shifts in the innovation agenda regarding its content; and (3) an increased societal awareness of public sector innovation that has become more transparent, with increased media attention, more external evaluation, and more transfer of innovative ideas and practices [7] (p. 8). The strength of Borins' framework lies in that the eight characteristics of innovation in public governments were derived from continuous comprehensive questionnaire surveys of local governments that allow facilitating research on current innovation and longitudinal comparison $[7,8]$. These characteristics emerged from a systematic analysis of real cases that provide a reliable reference for practical research on public sector innovation $[7,8]$. This is consistent with MONUM's innovative nature in the public sector. 
Table 1. Characteristics of innovation in public government according to Borins.

\begin{tabular}{|c|c|}
\hline Characteristics & Description \\
\hline Organizational change in the public sector & $\begin{array}{l}\text { Internal organizational improvement, often by importing } \\
\text { private sector practices (e.g., customer service enhancement, } \\
\text { total quality management, etc.). }\end{array}$ \\
\hline Process improvement & $\begin{array}{l}\text { When a process was made faster, more accessible, and friendlier, } \\
\text { or procedures for dealing with problems were simplified. }\end{array}$ \\
\hline Collaboration within the government & $\begin{array}{l}\text { Collaboration within one government and/or across levels of } \\
\text { government. }\end{array}$ \\
\hline External collaboration & Collaboration with the private and/or the nonprofit sector \\
\hline Citizen empowerment & $\begin{array}{l}\text { programs enhance the ability of individuals or groups to } \\
\text { overcome problems through their own initiative. }\end{array}$ \\
\hline Information technology & $\begin{array}{l}\text { ICT-supported institutional innovation by improving } \\
\text { transparency and citizens' access to and interactions with the } \\
\text { government. }\end{array}$ \\
\hline Use of market incentives & $\begin{array}{l}\text { Along with, or as substitutes for, regulation to bring about } \\
\text { socially desired behavior. }\end{array}$ \\
\hline Use of volunteers & To gain program objectives. \\
\hline
\end{tabular}

MONUM has planned and implemented a number of projects in five categories: streets, housing, engagement, education, and civic research. Table 2 describes each category according to MONUM's specific mission and objective.

Table 2. Category, Mission and Objective of the projects.

\begin{tabular}{cll}
\hline Category & \multicolumn{1}{c}{ Mission } & \multicolumn{1}{c}{ Objective } \\
\hline Street & $\begin{array}{l}\text { Making Boston's streets safer, more efficient, } \\
\text { and more delightful for all. }\end{array}$ & $\begin{array}{l}\text { To improve the flow of people } \\
\text { throughout the city. }\end{array}$ \\
\hline Housing & $\begin{array}{l}\text { Pioneer innovative housing models and } \\
\text { systems, as well as accelerating the pace of } \\
\text { innovation in the housing sector. }\end{array}$ & To increase housing affordability. \\
\hline \multirow{2}{*}{ Engagement } & $\begin{array}{l}\text { Government must create an open culture in } \\
\text { finding ways to make civic engagement } \\
\text { more meaningful for more people through } \\
\text { new technologies. }\end{array}$ & $\begin{array}{l}\text { To find new ways to create } \\
\text { democratic action in the 21st } \\
\text { century. }\end{array}$ \\
\hline & $\begin{array}{l}\text { Test ideas to improve education for people } \\
\text { in the city, including students, parents, } \\
\text { teachers, and other community members. }\end{array}$ & $\begin{array}{l}\text { To improve the systems that } \\
\text { support learning experiences in } \\
\text { Boston. }\end{array}$ \\
\hline Civic Research & $\begin{array}{l}\text { Quality and quantity of data and focus on } \\
\text { short-term and long-term results. }\end{array}$ & $\begin{array}{l}\text { To understand and explain civic } \\
\text { behaviors and needs for city } \\
\text { departments. }\end{array}$ \\
\hline
\end{tabular}

In order to investigate the agency's systemic approach to developing new urban policies, all projects have been re-categorized into eight common areas of intervention and analyzed through a correlation matrix (Table A1a-e, see the Appendix A). Intervention areas include ICTs, social relationships, built environment, mobility, health and safety, business, urban visioning and planning, and procedures and policies. The Table Ala-e in the Appendix A show the correlation matrix for each of the five categories listed in Table 2. 


\section{The Mayor's Office of New Urban Mechanics}

To understand the organizational and institutional peculiarities of the MONUM case, the first step was to examine its activities according to the eight innovation characteristics in public government $[7,8]$.

The characteristics of collaboration within the government and external collaboration were merged to better correspond to the systemic logic through which MONUM operates. Data derived from both primary and secondary sources demonstrated a correspondence between data sources and characteristics of innovation in the government, as is shown in Table 3.

Table 3. Correspondence between data sources and characteristics of innovation in the government.

\begin{tabular}{cc}
\hline Data Sources & Innovation Characteristics \\
\hline Web site, interviews, documents & Organizational change in the public sector \\
Web site, interviews, public presentations & Process improvement \\
Web site, interviews, public presentations & Collaboration within the government \\
Web site, interviews, public presentations & External collaboration \\
Web site, interviews, public presentations & Citizen empowerment \\
Web site & Information technology \\
Interviews, videos & Use of market incentives \\
\hline
\end{tabular}

In 2010, Thomas M. Menino, then Mayor of Boston, decided to establish the "Mayor's Office of New Urban Mechanics" (MONUM) to improve citizens' quality of life. Located in Boston's City Hall, the agency is part of the Mayor's Office. At that time, the Menino administration partially worked on innovation though never with a specific focus. Therefore, a work team devoted to innovation was established to better approach the future of Boston. The concept of "urban mechanics" came into being and was meant to overcome the averseness of risk and innovation often present in public administrations. The new team needed to explore the ground on which the government and citizens could work together to plan their city and respond to their needs.

By the beginning of Walsh's mayoral term in 2014, the size of MONUM's team and its scope had changed dramatically. The agency was not only kept but provided with more authority and support. The team received wide-ranging autonomy to experiment in new areas. This changed the MONUM's approach and organization, even though its main goal remained responding to people's needs with innovative solutions.

MONUM, as a public agency, takes risks that traditional city departments tend to be reluctant to do $[75,76]$. Pilot projects always follow a problem-solving rationale. When an experimentation succeeds, MONUM partners with one or more city departments to transform it into a permanent service. In case of failure, the team documents the lessons learned and shares them with partners and other cities around the world. In addition to pilot projects, MONUM acts as a "front-door" for start-ups, universities, and residents willing to experiment social innovation activities with the city. A mentoring activity is also carried out for other cities on how to establish innovation offices in their local governments.

Potential negative effects due to MONUM's high autonomy to experiment social innovation with risk-taking activities, such as confusion, chaos and poor quality of outcomes, are mitigated with highly organized and coordinated interventions from the public administration. Such interventions include systematic monitoring and assessment of the pilot projects to provide references to evidence-based public policy making.

\subsection{Organizational Change in the Public Sector}

Organizational change is the first characteristic of innovation in government that distinguishes MONUM from other types of public sector innovation. Public organizational change generally refers to internal improvement of the organization, which often occurs by introducing private sector 
practices, such as customer service improvement and service quality management [7]. The City of Boston had already made considerable progress in that direction when it introduced a collaborative problem-solving approach.

MONUM shows a reformed organizational structure (Figure 3). On the one hand, it has a traditional hierarchical structure: the agency is directly led by the Mayor and the team reports to two co-chairs who are in direct contact with the Mayor's staff and meet the Mayor weekly (Figure 3, right). This simplified vertical organization has enhanced the efficiency of the office in activating initiatives and projects, by allowing independence from other administrative departments and a direct connection to the political power. On the other hand, MONUM enjoys a considerable degree of autonomy. The work attitude and duties within MONUM are flexible. Rather than giving strong directives, MONUM encourages team members to pursue what they consider as relevant in producing evidence for public policies, being creative, and networking. However, they must meet the Mayor's priorities. One major difference from a traditional agency that usually operates on safe ground is that MONUM allows "failing": team members are encouraged to take risks, and failure is considered as important for the learning and knowledge-building process. This reformed organizational structure has created a "fuzzy area" of creativity and supported a horizontal collaborative approach to social innovation. This has ensured MONUM's agency to interact with all other public, private and civil entities in the city.

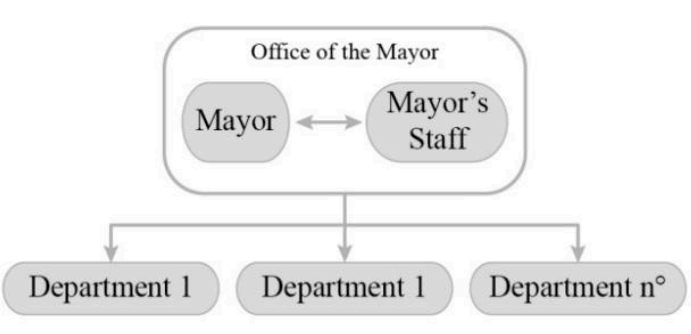

Administrative organizational structure before MONUM establishment

(a)

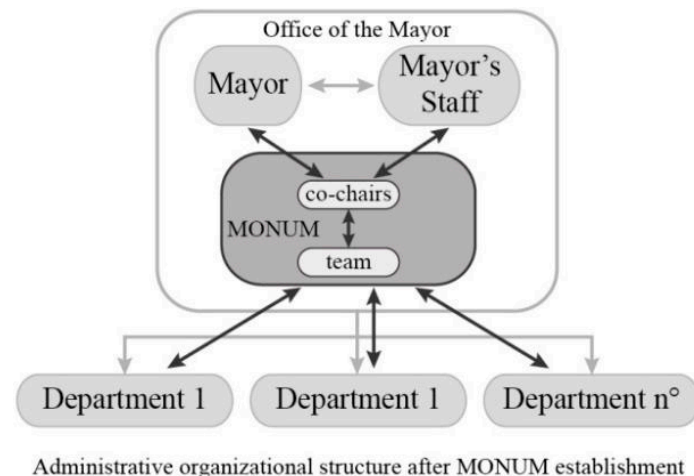

(b)

Figure 3. Administrative and organizational structure before (a) and after (b) MONUM's creation. (Source: Illustration by the authors).

\subsection{Improvement Process}

Improving an existing process means making it faster, more accessible, and friendlier [24] for citizens and employees. It also indicates simplification via ICTs and a better use of human resources for improved procedures.

MONUM is committed to its problem-solving civic research agenda [76]. It addresses questions raised during daily work, problems challenging the team, and required partnerships for problem solving. This work attitude moves within a paradigm that widely embraces an ecological perspective and systems theory [77-79]. Here, solutions to problems are achieved holistically. Such solutions treat the society as a whole, as opposed to the specialized, sectoral approach of the mechanized worldview [79]. MONUM's agenda democratizes the research process by being open to feedback and interaction. Unanswered questions and initial assumptions from the community's different perspectives are always welcome in urban policy $[80,81]$. For MONUM's team, civic research works as a conversation where observations and experiences count as much as hard numbers. Under the ecological paradigm, MONUM shifts from a hierarchy to a network [82]. Therefore, the public sector is seen as part of the community system where all elements produce and shape knowledge through a participatory process.

MONUM works on three levels: (1) project development; (2) technological transfer; and (3) knowledge transfer. Those levels come together under the broader philosophical umbrella of a new, 
innovative way of addressing public issues through multi-sectoral collaboration and social relationships among partners. The improvements achieved by MONUM benefit from methodologies such as "design thinking" and ICT-supported participatory processes.

A new project starts by raising questions and continues by listening to partners and potential stakeholders in order to reach an initial step of understanding. Eventually, local experts on the project's relevant matters are identified. Next, more questions are asked and data gathered. At this point, the established relationships allow for ideas and solutions to emerge. These are usually further analyzed by academics with the goal of developing an experimental prototype. Whether or not an experimental project is successful, the resulting knowledge is shared and made available for future use. If a project produces good results, it goes to the next stage, becoming permanent and eventually improved.

Table A1a-e in the Appendix A demonstrate that MONUM adopts "systems thinking" for project planning and implementation. Indeed, 46 projects implemented have addressed social, environmental, and economic issues in a systematic way, as all except for three projects had more than one intervention area that showed the interconnectedness between the three spheres. Intervention areas included social relationship (26 projects out of 46), ICTs (21/46), built environment (20/46), procedures and policies (18/46), urban visioning and planning (13/46), mobility (11/46), health and safety (8/46), and business (2/46) (Figure 4a). Twenty out of 46 projects cover three different intervention areas, 18 two, 5 four, and 3 projects only one (Figure $4 \mathrm{~b}$ ) (to be discussed in the following section).
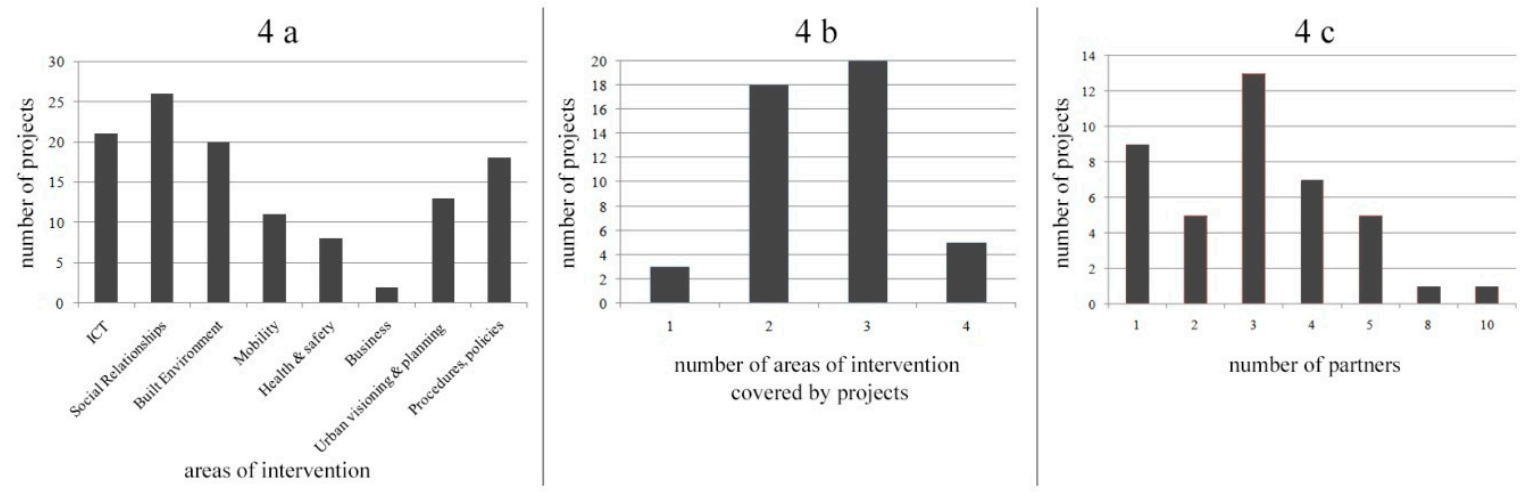

Figure 4. Evidence of the systemic approach adopted by MONUM: (a) number of projects per area of intervention; (b) number of projects per number of covered areas of intervention; (c) number of projects per number of partners that collaborated on a project. (Source: Image by the authors).

Another evidence of MONUM's "systems thinking" comes from the diversity of partnerships established in various projects. Its "systems thinking" approach benefits from cooperation among the actors from the civil society, which, having put them together into experimental projects of common interest, produced positive evidence (number and quality of the outcomes) regarding the adoption of a new dynamic organizational pattern in urban governance.

\subsection{Internal and External Collaboration}

Collaboration may occur within the government and/or across different governmental levels "internal" and/or with the private sector and/or nonprofit sector, which are considered "external" [7]. MONUM has established valuable partnerships and a know-how exchange mechanism, both at home and abroad. As component of the Mayor's Office, MONUM has been able to connect with various departments and people working on the city's problems. MONUM engages people with multidisciplinary expertise and shared values and vision. This broadens its projects' scope, areas of intervention, and partnerships. Although MONUM does not operate as a consultant beyond the scope of its own projects, it often helps the departments that fall into a gray area when it comes to responsibility. Consequently, it also works as a facilitator between public offices, researchers, start-ups, and local communities. 
Internal and external collaboration has been promoted by establishing partnerships. In fact, all of the 46 projects developed by MONUM, except for one, were implemented with partnership(s) (Figure 4c). A total of 119 partnerships were established, most of which were public-private. Yet, thirteen projects saw a partnership solely between public entities. In six cases, MONUM only partnered with private entities.

Apart from the internal and external collaboration at the local level, MONUM also established partnerships with other similar public agencies around the world. The most significant international partnerships were with public administrations of Copenhagen (Denmark) and Cluj-Napoca (Romania). Both cities established a municipal office focused on civil innovation [82,83], like MONUM does. To expand its international connections, MONUM has disseminated its work at various occasions in the USA and Europe. According to the interviewees, those international relationships are as valuable to MONUM as to their international partners. Such external collaboration has played a key role in promoting valuable knowledge exchange about similar models operating in different geopolitical contexts.

\subsection{Citizen Empowerment and Information and Communication Technologies}

Programs that help individuals or groups of people address problems by relying on their own initiative and resources tend to lead to citizen empowerment [24]. The experimental and participatory methods applied by MONUM require engaging a variety of actors from different societal sectors and making strong connections. The planning of new MONUM projects usually involves on-site investigations and direct communication with residents. The information helps conceptualize and implement strategies of empowerment. An example of citizen empowerment is the Community Plan IT project based on a game to find solutions to real-life problems by engaging more people in community issues and improving the feedback mechanism for urban planning.

Similarly, the 10-year master plan for the Chinatown area involved residents through the exploration of their living area by a character-driven virtual world. These kind of participatory method, using online interaction and in-person meetings, helped change the way in which people formulate and negotiate civic affairs with beneficial effects on both the community and municipal institutions. With regard to ICTs, the experimental nature of these projects facilitates learning based on citizens' use and modifies the technological design during construction. Peer-to-peer systems were also tested, for example, in the BOS:311 App project (later called Citizens Connect). This application nourishes residents' care for their communities by allowing them to report non-emergency issues and receive related solutions via smartphones.

These MONUM projects highlight how citizen empowerment activities became distinctive features of the Boston innovative urban governance model. Particularly, a sense of responsibility is fostered among citizens through certain programs which, by using ICTs, raise awareness of current issues and encourage people to proactively seek solutions. The use of ICTs can facilitate innovation in the public sector [8] by improving citizens' access to and interactions with various levels of government. For example, supporting public feedback to proposed regulations, facilitating public participation in the planning process, and contributing to guarantee public sector transparency.

In this perspective, the municipalities of San Francisco and Philadelphia established an innovation office [84] for a proactive utilization of ICTs. The rationale is to harness available open data and technological solutions to stimulate citizen participation in generating new ideas from those open sources [84]. The MONUM case is different in that ICTs have a complementary role in the innovation process. They are widely used, even though through a high infusion of research, relationship building, and a permanent learning process based on well-defined projects in which innovative solutions are generated. In the MONUM case, people are the main medium while ICTs and technological devices have a more passive role. They are adopted to produce data and information through their interaction with human beings, such as using applications and virtual reality. 
The initiative "Boston's Safest Driver Competition" was developed as a smartphone application in partnership with three public departments of the City of Boston and a private company. In order to obtain useful data for improving street security threatened by bad drivers, MONUM decided to leverage a competition among people in order to provide citizens with driving feedback. The idea included a driving competition motivating citizens to download and use the data-gathering app. A private insurance company provided monetary prizes as an additional incentive. Citizens competed with their family and friends while covering three million miles in three months. The experiment showed a reduction of risky behaviors, such as a $47 \%$ decrease in phone use and $35 \%$ speed reduction for the top 25 users. It also generated an amount of data that would be used to further develop street security projects and policies. Likewise, the Citizens Connect app facilitated the process of residents' empowerment in caring for their communities. Several apps developed within the MONUM projects were code-free, allowing other cities that use them to avoid the initial effort and development costs.

These examples show that MONUM distances itself from the narrow view of technology as a primary and undisputed role in producing innovation. Rather, it focuses on an ecologic worldview $[77,79]$ in which ICTs complement the experimentation process with new projects exploiting innovation-based solutions. This frees team members from focusing too much on technological solutions, allowing them to be more open-minded and creative in taking advantage of any available resources. This vision puts Boston's case among the public innovation programs that indicate the systemic approach as one of their main characteristics of innovation [24,75].

\subsection{Market Incentives and Volunteers}

Borins [24] recognized the use of market incentives as substitutes for regulation to bring about socially desired behavior. Market incentive strategies are sometimes applied by MONUM to projects when the participation of the private sector plays a relevant role. This was the case for the Density Bonus Pilot project. Launched in January 2017, this program incentivized developers in exchange for more affordable housing units. The strategy allowed developers into the program in order to increase the height or floor area of their units in exchange for an income restriction on a percentage of their residential units. For that purpose, the City created new density bonus zoning for two Strategic Planning Areas. The reasons for that program is that the City has been increasingly losing funding for affordable housing every year. Therefore, it is always looking for new ways to create more affordable housing units. These kinds of policies can create lots of new affordable housing without using public funds as incentives and will push developers to join the pilot program. Market incentives were implemented by MONUM in projects that needed leverage to gain the attention and involve necessary partners to make them successful, especially when the private sector constitutes the main partner.

The use of a volunteer workforce to gain program objectives is detected by Borins' study [7] with a frequency of $12 \%$ among the characteristics of innovation in the government. MONUM's public agency has no volunteers working within the office but, periodically, there are fellowships offered for collaborations open to individuals from different backgrounds and with a strong interest in innovation. Such individuals show creativity, curiosity, and entrepreneurial spirit. Further, a summer program offers the possibility of being involved in MONUM activities for a defined time. Overall, there is collaboration with people on a voluntary basis for specific projects due to on-site work with individuals and organizations from civil society.

We can conclude that although the Office does not envisage volunteers, the collaborative spirit of a common agenda that characterizes volunteering is present and strong under more defined forms. This can be found in several projects developed by MONUM.

\section{Discussions}

This research argues that MONUM can be seen as an evolution of public institutions that acknowledge a new governmentality aimed at tackling local socio-economic issues through innovative 
approaches. MONUM is essentially an open innovation lab dedicated to innovative evidence-based policy making.

Public sector organizations, being fuzziness-averse, are used to working with limited uncertainty where everything was framed by codes and clear agreements and no space is left for "institutional voids" or unclear rules and norms. MONUM is unconventional in that it supports a new urban governance pattern conducive to social innovation by taking advantage of the fuzziness $[32,33]$ that comes from the systemic nature of the innovation processes [31] and the dynamic organizational pattern (Figure 1b). At the organizational level, the fuzziness stems from a horizontal multi-sectoral collaboration mechanism (Figure 1a) made up of various entities from all societal sectors. The fuzziness on the condition of a multi-sectoral collaboration mechanism allows for a process of "open learning" and knowledge sharing among actors from all societal sectors. This complies with the modern innovation theory that emphasizes the open character of the learning process [85-89]. Through such a learning process, the production of innovation requires the cooperation among different entities that share ideas, knowledge and experience, and exchange staff and resources beyond traditional organizational borders [90,91]. This process plays a crucial role in strengthening its capability of addressing nested socio-economic issues through socially innovative practices [19]. In this respect, MONUM demonstrates the possibility of an effective urban governance through a new dynamic organizational pattern based on a horizontal multi-sectoral collaboration (Table 4). The new public agency's set-up, represented by MONUM, allowed for the pragmatic management of fuzziness in governance mechanisms by working with experimental projects and clear partnerships.

Table 4. Elements of the new dynamic organizational pattern in urban governance that emerged from the case study.

\begin{tabular}{|c|c|}
\hline Characteristics & MONUM Characteristics \\
\hline Change & $\begin{array}{l}\text { MONUM's organizational structure represents evidence of the need for an } \\
\text { institutional form of the public sector that operates in a new form of dynamic } \\
\text { organizational pattern in urban governance based on multi-sectoral societal } \\
\text { collaboration. }\end{array}$ \\
\hline Improvement & $\begin{array}{l}\text { The process improvement derived from adopting a systems thinking approach } \\
\text { produced positive evidence (number and quality of the outcomes) about the } \\
\text { adoption of a new dynamic organizational pattern in urban governance based on a } \\
\text { horizontal multi-sectoral collaboration and socially innovative practices. }\end{array}$ \\
\hline Collaboration & $\begin{array}{l}\text { Collaboration activity produced valuable results for MONUM as it has led to } \\
\text { establishing new partnerships and exchange know-how with similar agencies } \\
\text { worldwide. }\end{array}$ \\
\hline Empowerment & $\begin{array}{l}\text { Citizen empowerment at MONUM manifests through programs that foster } \\
\text { responsibility in citizens, raising their awareness about issues and then pushing } \\
\text { them to seek solutions. }\end{array}$ \\
\hline Innovation & $\begin{array}{l}\text { In the Boston MONUM case, ICT has a complementary role of data gathering and } \\
\text { support of project developments for local engagement. }\end{array}$ \\
\hline Leverage & $\begin{array}{l}\text { MONUM uses market incentives as leverage to engage necessary partners for } \\
\text { starting and developing projects. This is more frequent in private sector } \\
\text { collaborations. }\end{array}$ \\
\hline Civic engagement & $\begin{array}{l}\text { The use of volunteers within the Office is not envisaged, but the spirit of } \\
\text { collaboration characterizing volunteering is reflected in the action and behavior of } \\
\text { individuals and civil society groups engaged with MONUM on specific projects. }\end{array}$ \\
\hline
\end{tabular}

The table above (Table 4) shows that the MONUM case complies with the eight characteristics of innovation in public government, revealing a new dynamic organizational pattern in urban governance in addressing societal problems. These findings are in line with the EU's objectives of promoting social innovation to enhance social cohesion. European cities face a common challenge, that is, how to collaborate with citizens and harness the potential benefits of social innovation. It is therefore 
commendable to conduct a preliminary comparison between the MONUM findings and the key characteristics of two European best practices of social innovation, i.e. Amersfoort (Netherlands) and Gdańsk (Poland) highlighted in the URBACT report "Social Innovation in Cities" [36]. This paper chose Amersfoort and Gdańsk as two contrasting cases: while the former is an advanced one which is experimenting with leading-edge innovations, the latter is a developing one which is starting engagement with social innovation and citizens.

The preliminary comparison presented in Table 5 is meant to reveal the similarities and differences of urban governance approaches to social innovation between the USA and the EU. It also allows outlining the organizational response of the public sector to citizens' needs that may differ with respect to the different social, economic, political and, above all, administrative contexts. Other studies would be needed to assess the impacts of these approaches in order to set out useful indicators for testing and evaluating the transferability of the lessons learnt to European cities.

Table 5. Similarities and differences from the governance perspective between MONUM case key characteristics and EU best practices [36].

\begin{tabular}{|c|c|c|}
\hline $\begin{array}{c}\text { MONUM } \\
\text { Characteristics }\end{array}$ & Amersfoort & Gdańsk \\
\hline Change & $\begin{array}{l}\text { Changing towards a more collaborative urban } \\
\text { governance between the city administration and } \\
\text { citizens. }\end{array}$ & $\begin{array}{l}\text { Reforming the traditional hierarchical } \\
\text { city administration system. }\end{array}$ \\
\hline Improvement & $\begin{array}{l}\text { Public administration is shifting from a power role' } \\
\text { to one of a 'learning administration'; fostering } \\
\text { multi-disciplinarity and collaboration between the } \\
\text { different departments; promoting transparency in } \\
\text { public action; being less expert and more able to } \\
\text { connect; making interdependent and integrated } \\
\text { policies; fostering responsibility beyond silos; and } \\
\text { learning how to learn from failures. }\end{array}$ & $\begin{array}{l}\text { City administration is promoting } \\
\text { horizontal multi-sectoral collaboration } \\
\text { in order to avoid administrative silos. }\end{array}$ \\
\hline Collaboration & $\begin{array}{l}\text { New forms of collaboration between citizens and the } \\
\text { city administration, such as the New Collaboration } \\
\text { conference, the G1000, Project Start-up. }\end{array}$ & $\begin{array}{l}\text { The municipality has extended its } \\
\text { cooperation and partnership with } \\
\text { NGOs for which a specific unit was set } \\
\text { up within the City administration. }\end{array}$ \\
\hline Empowerment & $\begin{array}{l}\text { Empowerment was achieved through the } \\
\text { collaborative design and implementation of } \\
\text { citizen-driven projects (e.g., the Elisabeth project, the } \\
\text { Sustainable Food process). }\end{array}$ & $\begin{array}{l}\text { Citizens were involved in (1) } \\
\text { consultation processes and enabled to } \\
\text { choose which city projects should take } \\
\text { priority for funding; and (2) co-creation } \\
\text { process. }\end{array}$ \\
\hline Innovation & $\begin{array}{l}\text { The Municipality deployed ICTs to support citizen } \\
\text { reorganization. }\end{array}$ & $\begin{array}{l}\text { The municipality, together with NGOs, } \\
\text { has supported innovation by creating } \\
\text { online platforms for co-creation. }\end{array}$ \\
\hline Leverage & No market incentives were reported. & No market incentives were reported. \\
\hline Civic engagement & $\begin{array}{l}\text { Citizens are not only users of social innovation } \\
\text { results, but co-designers and co-creators of solutions. }\end{array}$ & $\begin{array}{l}\text { Citizens are not only users of social } \\
\text { innovation results, but co-designers } \\
\text { and co-creators of solutions. }\end{array}$ \\
\hline
\end{tabular}

The two best practices selected by URBACT show some similarities with and differences from the MONUM case. This allows for a preliminary comparative analysis of key characteristics of social innovation under different geopolitical contexts. The first similarity lies in the common need for "change" coming from citizens and local communities. Both in the USA and the EU, cities' traditional operational system of public administration seems inadequate to address the current socio-economic needs. This is especially true in Europe where the public administration regulates all the aspects of citizens' lives. There is an evident mismatch between the multi-level socio-economic needs of citizens and public administrations' limited ability to respond. The current response by public administrations both in the USA and the EU is characterized by multi-sectoral and horizontal collaborations among departments to prevent silos effect (especially in the EU), citizen involvement and empowerment through a proactive participation in leading social innovation projects, and multi-stakeholder collaboration among all the 
three societal sectors. Another similarity is that ICTs have been deployed in all cases as an important tool to empower and engage citizens in social innovation initiatives.

One noticeable difference is the leverage factor of social innovation. Market incentives in the MONUM case have played a stronger role than in the European cases. In the MONUM case, market incentives were provided to make social innovation projects attractive to the private sector, and therefore build up public-private partnerships to promote the social innovation process. In the European cases, the public sector was the key funder with a minor role played by the private sector. Additionally, the social innovation process has been leveraged mainly through operating initiatives that stimulate citizen engagement and participation [36].

The emerging new role of the public sector, as MONUM represents in facilitating social innovation in urban governance through public institutional reforms, poses two main questions: (1) how much innovation will be generated, inclusively used, and fairly distributed by initiatives such as MONUM?; and (2) how far the new approach will take root? The first question is about change in usual practice and equity of social innovation, whereas the second is about how to innovate within practice and the public administration in a continuous process. The answer to these two questions demands a critical lens of MONUM's operation, which, despite all its organizational innovation and cross-cutting social innovation practices, is not free of potential limitations and risks. First of all, power asymmetries due to the predominant market-oriented context where such social innovation initiatives take place could undermine the effectiveness of citizen participation and multi-stakeholder partnerships. Indeed, participatory circumstances are decidedly non-ideal in many cases, marked by power asymmetries that often undermine the negotiation power of underprivileged social groups regarding issues of their interests. Consequently, the uneven interaction amongst stakeholders in terms of know-how and influence tends to pave the way for manipulative orchestrations in networking governance platforms [28]. Second, it is not unrealistic to question the sustainability of the participatory and multi-stakeholder partnership approach to lead social innovation initiatives, considering the inevitable presence of competing perspectives in the highly variegated civil society like Boston. All in all, how to prevent social innovation initiatives facilitated by public institutional reform from blurring competing perspectives, creating policy closures, and absorbing dissident societal voices, proves a highly relevant issue to investigate $[92,93]$.

\section{Conclusions}

MONUM represents a new urban governance model in the form of a public agency operating in a market-oriented society and conducive to processes of social innovation. On the public sector side, the MONUM case positively indicates a way to approach the need for changes in contemporary urban governance. This approach requires the evolution of existing institutional forms from a static, hierarchical organization towards an organizational structure based on evidence-based and socially innovative practices and horizontal collaboration across the three societal sectors (Figures $1 \mathrm{~b}$ and 5). One of the most significant innovative practices of MONUM is its evidence-based (project-based) and multi-stakeholder partnership approach to problem-solving that constitutes a significant change in usual practice within the public sector. This working model operates in a non-linear way, incorporating any elements of the urban governance system that can potentially influence positively the final result. Therefore, the dynamic of the new organizational paradigm of MONUM requires new operating methods that embrace creativity in problem solving and the acceptance of risk-taking in a climate of uncertainty. The case study analyses suggest that, first, the peculiarity of MONUM lies in its hybrid and boundary-blurring nature. Such a nature manifests itself as public responsiveness towards civil society, while operating through methods and techniques common to the private sector. Second, new institutional forms that experiment with urban governance can rely on a multi-sectoral collaboration. Through flexible alignment of actors from public, private and civil entities with coherent political will and budget support, MONUM has activated a series of community-based projects to address cross-cutting socio-economic issues. These aspects demonstrate reorganization, interdisciplinarity 
and interrelationship as three fundamental characteristics of innovation [54]. Besides, multi-sectoral collaboration seems to help improve the quality of project outputs. According to the opinion of the interviewees, the best projects are those with a collaboration between various societal entities. Third, MONUM has experimented with a systemic approach to social innovation in accordance with the "design thinking theory." Murray and others [22] expounded on this theory with six key stages in the nonlinear process that social innovation usually goes through: prompts, proposals, prototyping, sustaining, scaling and diffusion, as well as systemic change [94,95]. MONUM's methodology is a systemic one as it aims at developing evidence-based policies by following all such stages (Figure 5), thereby creating a system of "feedback loop." This assures a permanent learning process producing outputs with systemic impact and sensitive to local context and community needs, as is shown from the analysis of MONUM projects (Figure $4 \mathrm{a}-\mathrm{c}$ ). Its systemic approach is also evidenced by the fact that its projects were all, firstly, based on a multi-sectoral collaboration among all the three societal sectors; and secondly, with cross-cutting intervention areas that cover all social, economic and environmental spheres.

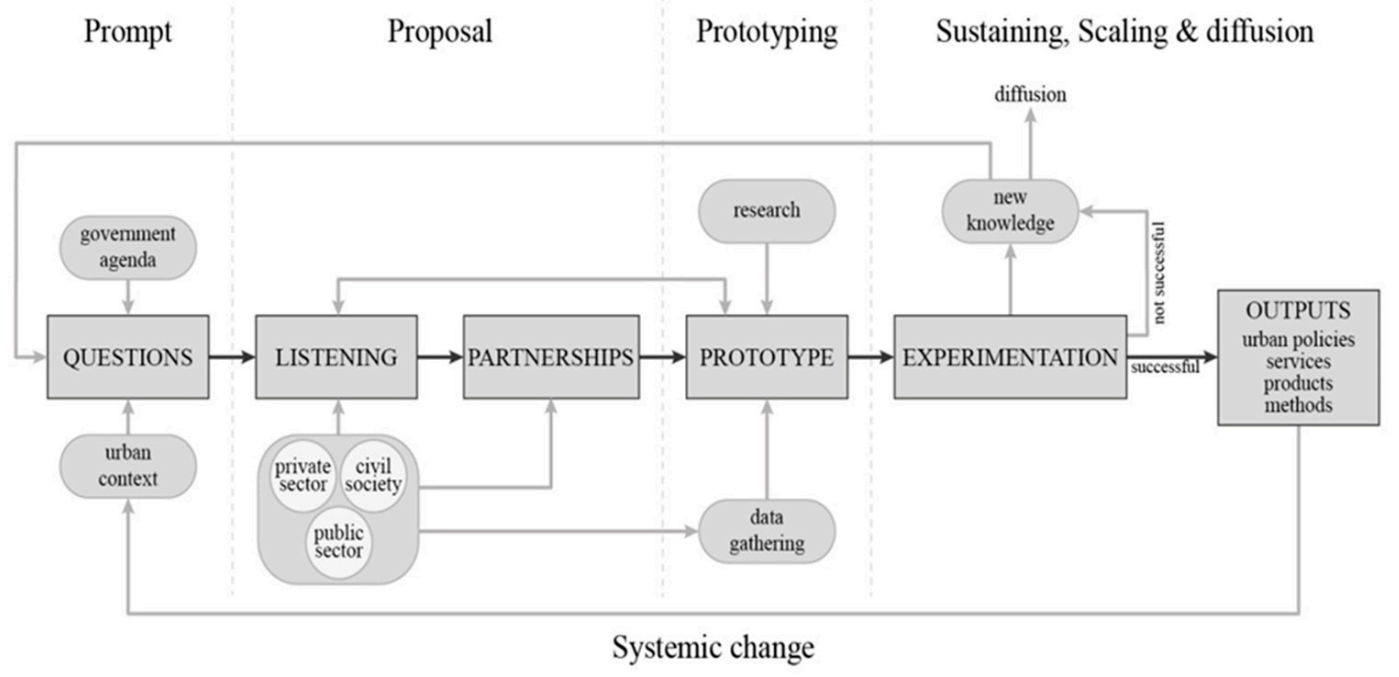

Figure 5. MONUM's operative process (Source: Image by the authors).

The implications of the MONUM case appear twofold. From the public sector's perspective, they can inspire public officers seeking to improve the efficiency and transparency of public administration, and address local socio-economic issues with a systemic approach. From the community's perspective, they can offer more empowerment and engagement opportunities for citizens, allowing for the dynamic interaction with a responsive public sector. Policy makers from the public sector and researchers who explore the future of cities and urban governance with a close attention to innovation in all fields may benefit from this research. The boundary-blurring MONUM case makes it ideal for further research from a civil society and private sector perspective, which is unchartered here. However, the analysis of the MONUM case indicates market incentives as a leveraging element in the social innovation projects. The leveraging mechanism consisted in a bonus formula for private developers involved in the projects committed to realizing affordable housing units. This process helped pool private financial resources for the social innovation initiatives promoted by the MONUM office.

The MONUM case can contribute to the current debate in Europe on the need to harmonize EU policies for an effective social inclusion by promoting the application of place-sensitive approach [12]. To meet such a need, promoting institutional improvement, rather than merely enhancing education and training, is crucial to build up the innovation capacities and stimulate entrepreneurship at the local level [12]. If the place-sensitive approach is characterized by the need of improvements in government, for instance through the promotion of e-government to improve transparency and effectively engage the 
civil society in any development intervention [12], then the MONUM case provides useful references for EU lagging regions and cities. For example, the application of ICTs in urban governance could support knowledge generation and sharing in those areas where agglomeration and density are lacking. Mindful of the socio-economic and political differences between the USA and the EU, this research is not meant to replicate the MONUM model in European cities. Rather, it is aimed to identify contributing factors to social innovation initiatives from the urban governance perspective. These factors can be useful references for designing social innovation initiatives and being adaptable to different institutional and administrative systems. Moreover, experimenting the model as MONUM represents under non-market-oriented contexts could inspire and help European cities develop more effective social innovation policies and projects (e.g., integrating market incentives).

Despite that the present work marks the initial step of a research pathway, the MONUM case has provided helpful evidence for identifying key elements of a new public organizational form supportive of social innovation practices. This, combined with the preliminary analytical comparison with EU best practices, represents the first step for further researches offering a possible framework to structure the change factors that public organizations need to address to spur social innovation. Such a framework is critical to guide further analyses on how public organizational change can favor social innovation to generate socio-economic benefits for local communities. Starting from this initial research work, upcoming research activities may, on the one hand, further the analysis of MONUM's socio-economic impacts on local communities. On the other hand, it is desirable to carry out a more critical and systematic comparative analysis of MONUM and EU cases. These two fields of work will help identify and define indicators for measuring social innovation-oriented policies (in terms of their impacts), and test and evaluate the transferability of the lessons learnt to European cities.

In this direction, further research work may, first, integrate quantitative data on socio-economic, financial and physical contexts into the analytical discussions to understand how the implementation of these ICT-based solutions in urban governance affect local communities and how such initiatives are funded. A preliminary analysis of the City of Boston Fiscal Year 2020 revealed how the Operating Budget for the New Urban Mechanics Initiatives increased constantly since its operation in 2014 (over $\$ 400,000.00$ ). Second, deepened comparative analyses of social innovation initiatives supported by public institutional reforms from the USA and the EU seems a promising research branch. Thereby, it is expected to develop and improve existing social innovation models applicable to EU lagging cities and regions. In view of the reform agenda of the post-2020 programming of the EU Cohesion Policy, this is critical to help narrow the gap between urban and inner areas, and between core and lagging cities and regions.

Author Contributions: C.B. conceived and designed the case study analysis, methodology, supervision; Y.O. performed the literature review, writing—-review \& editing; P.P. performed the analysis and data curation and G.M.: writing - original draft preparation, conceptualization and performed the analysis. All authors have read and agreed to the published version of the manuscript.

Funding: This research is part of the TREnD project (Transition with Resilience for Evolutionary Development), which has received funding from the European Union's Horizon 2020 research and innovation program under the Marie Skłodowska-Curie grant agreement No. 823952.

Acknowledgments: The authors extend their appreciation to the Mayor's Office at New Urban Mechanics in Boston, Massachusetts and the School of Public Policy and Urban Affairs at Northeastern University, also of Boston. Everyone provided assistance during this research.

Conflicts of Interest: The authors declare no conflict of interest. 


\section{Appendix A}

Table A1. Correlation matrix: Category: (a) Streets; (b) Housing; (c) Engagement; (d) Education; (e) Civic Research.

(a)

\begin{tabular}{|c|c|c|c|c|c|c|c|c|c|c|c|}
\hline \multirow{2}{*}{ Project Name } & \multirow{2}{*}{$\begin{array}{l}\text { Partner } \\
\text { Type n }^{\circ}\end{array}$} & \multirow{2}{*}{ Project Description } & \multirow{2}{*}{ Specific Objective } & \multicolumn{8}{|c|}{ Areas of Intervention * } \\
\hline & & & & A & B & $\mathrm{C}$ & D & $\mathrm{E}$ & F & G & $\mathrm{H}$ \\
\hline $\begin{array}{l}\text { Autonomous } \\
\text { vehicles Boston's } \\
\text { approach }\end{array}$ & $\begin{array}{l}\text { PUB } 1 \\
\text { PRIV } 3\end{array}$ & $\begin{array}{l}\text { Learn more about our plans for testing autonomous vehicles and their } \\
\text { potential future in the City of Boston. }\end{array}$ & Safer streets better access, better reliability. & & & & $\mathrm{x}$ & & & & \\
\hline Drive Boston & $\begin{array}{l}\text { PUB } 2 \\
\text { PRIV } 2\end{array}$ & $\begin{array}{l}\text { The City's program provides parking spaces in municipal lots and on City } \\
\text { streets for cars-hare vehicles. }\end{array}$ & Better access. & & & $\mathrm{x}$ & $\mathrm{x}$ & & & & \\
\hline $\begin{array}{c}\text { Boston's safest } \\
\text { driver competition }\end{array}$ & $\begin{array}{l}\text { PUB } 2 \\
\text { PRIV } 2\end{array}$ & $\begin{array}{l}\text { Boston's safest driver competition is a smartphone app that provides you } \\
\text { helpful feedback on your driving. }\end{array}$ & Safer driving. & $\mathrm{x}$ & $x$ & & $\mathrm{x}$ & $\mathrm{x}$ & & & \\
\hline Smart Parking & $\begin{array}{l}\text { PUB } 2 \\
\text { PRIV } 1\end{array}$ & $\begin{array}{l}\text { A smart parking initiative in Boston's Innovation District to connect rivers } \\
\text { with vacant spots by giving them real-time information on open spaces. }\end{array}$ & To give potential drivers real time parking information. & $\mathrm{x}$ & & $\mathrm{x}$ & $\mathrm{x}$ & & & & \\
\hline City worker app & $\begin{array}{l}\text { PUB } 2 \\
\text { PRIV } 1 \\
\end{array}$ & $\begin{array}{l}\text { It is an app that gives to city workers real- time access to the City's internal } \\
\text { systems while they're in the field. }\end{array}$ & To improve the City's response time for service requests. & $\mathrm{x}$ & & $\mathrm{x}$ & & & & & \\
\hline $\begin{array}{l}\text { LED street name } \\
\text { signs }\end{array}$ & $\begin{array}{l}\text { PUB } 1 \\
\text { PRIV } 0\end{array}$ & Street name signs lit by LED lights. & To make streets safer for pedestrians at night. & & & $\mathrm{x}$ & $\mathrm{x}$ & $\mathrm{x}$ & & & \\
\hline $\begin{array}{l}\text { Neighborhood slow } \\
\text { street }\end{array}$ & $\begin{array}{l}\text { PUB } 1 \\
\text { PRIV } 7\end{array}$ & $\begin{array}{l}\text { A City initiative to slow traffic speeds and improve safety on residential } \\
\text { street within specific area. When a neighborhood is part of the program } \\
\text { the speed limit on its residential street will be } 20 \mathrm{MPH} \text {. }\end{array}$ & $\begin{array}{l}\text { To reduce the number and severity of crashes on } \\
\text { residential streets, lessen the impacts of cut-through } \\
\text { traffic, and add to the quality of life in our } \\
\text { neighborhoods. }\end{array}$ & & $\mathrm{x}$ & $\mathrm{x}$ & $\mathrm{x}$ & $\mathrm{x}$ & & & \\
\hline Vehicle side guards & $\begin{array}{l}\text { PUB } 2 \\
\text { PRIV } 0 \\
\end{array}$ & $\begin{array}{l}\text { Installation of vehicle side guards on } 18 \text { Public Works trucks to reduce the } \\
\text { risk to cyclists in the case of a crash. }\end{array}$ & To reduce the risk to cyclists in the case of a crash. & & & & $\mathrm{x}$ & $\mathrm{x}$ & & & \\
\hline Street bump & PUB OPRIV 5 & $\begin{array}{l}\text { A mobile app that gathers data about Boston's streets using a } \\
\text { smartphone's built-in sensors as a resident drive. }\end{array}$ & To plan long-term infrastructure improvements. & $\mathrm{x}$ & & $\mathrm{x}$ & $\mathrm{x}$ & & & & \\
\hline Adopt a hydrant & $\begin{array}{l}\text { PUB } 2 \\
\text { PRIV } 0\end{array}$ & $\begin{array}{l}\text { Through the platform, participants locate one of the more than } 13,000 \\
\text { public fire hydrants in the City. They then name it and commit to clearing } \\
\text { the hydrant of snow after a snowstorm. }\end{array}$ & To make sure a specific fire hydrant is cleared of snow. & $\mathrm{x}$ & $\mathrm{x}$ & $\mathrm{x}$ & & & & & \\
\hline $\begin{array}{l}\text { Boston Parklet } \\
\text { Program }\end{array}$ & $\begin{array}{l}\text { PUB } 1 \\
\text { PRIV } 0\end{array}$ & $\begin{array}{l}\text { Parklets create seasonal pedestrian space, improving the quality of life in } \\
\text { Boston's neighborhoods and commercial corridors. }\end{array}$ & $\begin{array}{l}\text { To offer residents and local businesses greater public } \\
\text { space on which to gather and relax. }\end{array}$ & & $\mathrm{x}$ & $\mathrm{x}$ & & & & & \\
\hline Soofa & $\begin{array}{l}\text { PUB } 1 \\
\text { PRIV } 4\end{array}$ & $\begin{array}{l}\text { A solar-powered seat that can charge smartphones and collect data on the } \\
\text { environment. }\end{array}$ & $\begin{array}{l}\text { To building greener, smarter, and more } \\
\text { pedestrian-friendly streets. }\end{array}$ & $\mathrm{x}$ & & $\mathrm{x}$ & & & & & \\
\hline Smart streets & $\begin{array}{l}\text { PUB } 3 \\
\text { PRIV } 1\end{array}$ & $\begin{array}{l}\text { We use technology to learn more about how people navigate and interact } \\
\text { on and with the City's street. }\end{array}$ & $\begin{array}{l}\text { To capture aggregated data that helps us better } \\
\text { understand the hazards on our roads and improve } \\
\text { street design and safety. }\end{array}$ & $\mathrm{x}$ & & $\mathrm{x}$ & $\mathrm{x}$ & $\mathrm{x}$ & & & \\
\hline $\begin{array}{l}\text { Performance } \\
\text { parking pilot }\end{array}$ & $\begin{array}{l}\text { PUB } 3 \\
\text { PRIV } 0\end{array}$ & $\begin{array}{l}\text { We are studying how the City can use flexible meter rates to reduce the } \\
\text { amount of time it takes to find a parking space. }\end{array}$ & $\begin{array}{l}\text { To set more parking spots aside for those trying to get to } \\
\text { our busiest neighborhoods. }\end{array}$ & $\mathrm{x}$ & & & $\mathrm{x}$ & & & & \\
\hline
\end{tabular}

* Area of intervention: A (ICT); B (Social Relationships); C (Built Environment); D (Mobility); E (Health \& Safety); F (Business); G (Urban visioning\& Planning); H (Procedures \& Policies). 
Table A1. Cont.

(b)

\begin{tabular}{|c|c|c|c|c|c|c|c|c|c|c|c|}
\hline \multirow{2}{*}{ Project Name } & \multirow{2}{*}{$\begin{array}{l}\text { Partner } \\
\text { Type }^{\circ}\end{array}$} & \multirow{2}{*}{ Project Description } & \multirow{2}{*}{ Specific Objective } & \multicolumn{8}{|c|}{ Areas of Intervention * } \\
\hline & & & & A & B & C & D & E & $F$ & G & $\mathbf{H}$ \\
\hline $\begin{array}{l}\text { Compact Living } \\
\text { Pilot }\end{array}$ & $\begin{array}{l}\text { PUB } 4 \\
\text { PRIV } 2\end{array}$ & $\begin{array}{l}\text { The City is allowing new buildings to include small, efficient housing units } \\
\text { as long as they meet certain requirements. }\end{array}$ & $\begin{array}{l}\text { To build more homes that are well-designed and well } \\
\text { located, and to create living spaces where people have } \\
\text { easy access to work and play }\end{array}$ & & & $\mathrm{x}$ & & & & $\mathrm{x}$ & $\mathrm{x}$ \\
\hline $\begin{array}{l}\text { Plugin house } \\
\text { initiative }\end{array}$ & $\begin{array}{l}\text { PUB } 1 \\
\text { PRIV } 3\end{array}$ & $\begin{array}{l}\text { The Plugin House demonstrates the possibilities of backyard homes and } \\
\text { smaller living to provide housing affordable to all. }\end{array}$ & $\begin{array}{l}\text { To provide opportunities for infill of vacant areas and } \\
\text { additions in backyards to address the housing crisis. }\end{array}$ & & & $\mathrm{x}$ & & & & $\mathrm{x}$ & \\
\hline $\begin{array}{l}\text { Housing with Public } \\
\text { Assets }\end{array}$ & PUB 9PRIV 1 & $\begin{array}{l}\text { Could building housing on top of, or next to, city buildings, such as } \\
\text { libraries and community centers, benefit our communities? }\end{array}$ & To bring down costs and benefit communities. & & & $\mathrm{x}$ & & & & $\mathrm{x}$ & \\
\hline $\begin{array}{l}\text { Urban Housing unit } \\
\text { roadshow }\end{array}$ & $\begin{array}{l}\text { PUB } 1 \\
\text { PRIV } 4\end{array}$ & $\begin{array}{l}\text { The Urban Housing was a compact apartment on wheels. We took it from } \\
\text { downtown Boston to Roslindale, Mattapan, Dorchester, Roxbury and Est } \\
\text { Boston. Through our interactive exhibit, we heard from the community } \\
\text { about what they think about smaller living. }\end{array}$ & $\begin{array}{l}\text { To bear what residents thought about smaller living. To } \\
\text { show people how smaller spaces can offer livability and } \\
\text { comfort at a good price. }\end{array}$ & & $\mathrm{x}$ & $\mathrm{x}$ & & & & & \\
\hline $\begin{array}{l}\text { Housing innovation } \\
\text { competition }\end{array}$ & $\begin{array}{l}\text { PUB } 1 \\
\text { PRIV } 2\end{array}$ & $\begin{array}{l}\text { We asked development teams to propose innovative compact living } \\
\text { designs. The subjects of the competition were five city-owned properties } \\
\text { in the Garrison Trotter neighborhood. The winning proposals in the } \\
\text { competition would be built there. }\end{array}$ & To show that small, affordable family units are feasible. & & $\mathrm{x}$ & $\mathrm{x}$ & & & & & \\
\hline Density Bonus pilot & $\begin{array}{l}\text { PUB } 2 \\
\text { PRIV } 0\end{array}$ & $\begin{array}{l}\text { The Program gives developers incentives in exchange for more affordable } \\
\text { units. }\end{array}$ & To create more affordable units. & & & $\mathrm{x}$ & & & $\mathrm{x}$ & & $\mathrm{x}$ \\
\hline $\begin{array}{l}\text { Clearing up the } \\
\text { homebuying process }\end{array}$ & $\begin{array}{l}\text { PUB } 2 \\
\text { PRIV } 0\end{array}$ & A new homebuying framework. & $\begin{array}{l}\text { To better support first-time buyers through the complex } \\
\text { process. }\end{array}$ & & & & & & & & $\mathrm{x}$ \\
\hline $\begin{array}{l}\text { Addition dwelling } \\
\text { unit pilot }\end{array}$ & $\begin{array}{l}\text { PUB } 3 \\
\text { PRIV } 0\end{array}$ & $\begin{array}{l}\text { A 18-month pilot program for owner occupants in East Boston, Mattapan, } \\
\text { and Jamaica Plain. They can carve out space within their home to create } \\
\text { smaller, independent rental units (ADUs). }\end{array}$ & $\begin{array}{l}\text { To lower the cost of living in Boston. To prevent } \\
\text { displacement. To develop more natural affordable } \\
\text { housing options. }\end{array}$ & & & $\mathrm{x}$ & & & $\mathrm{x}$ & & $\mathrm{x}$ \\
\hline $\begin{array}{l}\text { Intergenerational } \\
\text { home-share pilot }\end{array}$ & $\begin{array}{l}\text { PUB } 2 \\
\text { PRIV } 1\end{array}$ & $\begin{array}{l}\text { Exploring different housing options in communities through a } \\
\text { "Home-share" network. This network matches older homeowners with } \\
\text { extra rooms to rent to people who need to rent a room. }\end{array}$ & $\begin{array}{l}\text { To open up new affordable rental units. To create } \\
\text { sustainable living environment that support residents as } \\
\text { they age in their homes. }\end{array}$ & & $\mathrm{x}$ & & & & & & $\mathrm{x}$ \\
\hline
\end{tabular}

*Area of intervention: A (ICT); B (Social Relationships); C (Built Environment); D (Mobility); E (Health \& Safety); F (Business); G (Urban visioning\& Planning); H (Procedures

\& Policies). 
Table A1. Cont.

(c)

\begin{tabular}{|c|c|c|c|c|c|c|c|c|c|c|c|}
\hline \multirow{2}{*}{ Project Name } & \multirow{2}{*}{$\frac{\text { Partner }}{\text { Type n }^{\circ}}$} & \multirow{2}{*}{ Project Description } & \multirow{2}{*}{ Specific Objective } & \multicolumn{8}{|c|}{ Areas of Intervention * } \\
\hline & & & & A & В & C & D & E & F & G & $\mathbf{H}$ \\
\hline Community made & $\begin{array}{l}\text { PUB } 1 \\
\text { PRIV } 1 \\
\end{array}$ & A partnership with civic crowdfunding platform ioby.org. & To support the creation of "third spaces" around Boston. & & $\mathrm{x}$ & $\mathrm{x}$ & & & & $\mathrm{x}$ & $\mathrm{x}$ \\
\hline Beta blocks & PUB OPRIV 3 & Exploring new approaches for community-led innovation in public spaces. & $\begin{array}{l}\text { To build more meaningful relationships between } \\
\text { communities that have a challenge and the companies, } \\
\text { researchers, designers, and artists who might be able to } \\
\text { offer a job. }\end{array}$ & $x$ & $\mathrm{x}$ & & & & & $x$ & $\mathrm{x}$ \\
\hline Play around the city & PUB OPRIV 0 & $\begin{array}{l}\text { When we add playfulness to untraditional spaces, we increase learning } \\
\text { and resilience habits across the City. }\end{array}$ & $\begin{array}{l}\text { To build on existing space-based play areas, such as our } \\
\text { playgrounds and parks. To create a city where everyone } \\
\text { feels welcomed and empowered to playfully imagine } \\
\text { more. }\end{array}$ & & $\mathrm{x}$ & & & & & $\mathrm{x}$ & $\mathrm{x}$ \\
\hline Boston basic Nudges & PUB OPRIV 0 & $\begin{array}{l}\text { Using MBTA Bus Stop PSAs to encourage to build Boston Basic into daily } \\
\text { commutes. }\end{array}$ & $\begin{array}{l}\text { To encourage folks, especially families with wee ones, to } \\
\text { build Boston basic into daily commutes. }\end{array}$ & & $\mathrm{x}$ & & & $\mathrm{x}$ & & & $\mathrm{x}$ \\
\hline $\begin{array}{l}\text { Participatory } \\
\text { pokemon go }\end{array}$ & $\begin{array}{l}\text { PUB } 1 \\
\text { PRIV } 3\end{array}$ & $\begin{array}{l}\text { We'll work with middle school and high school students to choose the sites } \\
\text { of new "Pokéstops" for Pokémon GO. }\end{array}$ & To identify meaningful locations. & $\mathrm{x}$ & $\mathrm{x}$ & & & & & & \\
\hline $\begin{array}{l}\text { BOS311 App- } \\
\text { Citizens Connect }\end{array}$ & $\begin{array}{l}\text { PUB } 2 \\
\text { PRIV } 1\end{array}$ & $\begin{array}{l}\text { Residents report non-emergency issues with the City directly from their } \\
\text { smartphones. These get sent into the City's work order management } \\
\text { system, which then sends it to the right person in City Hall. }\end{array}$ & $\begin{array}{l}\text { To empower residents to help take care of their } \\
\text { communities. }\end{array}$ & $\mathrm{x}$ & & & & & & & $\mathrm{x}$ \\
\hline Community PlanIt & PUB 0PRIV 1 & $\begin{array}{l}\text { Community PlanIt is a game that makes planning playful. It includes } \\
\text { online interaction and in-person meetings. }\end{array}$ & $\begin{array}{l}\text { To create a bigger and more engaged audience for } \\
\text { community talks. }\end{array}$ & $\mathrm{x}$ & $\mathrm{x}$ & & & & & $\mathrm{x}$ & \\
\hline Block quotes & $\begin{array}{l}\text { PUB } 1 \\
\text { PRIV } 2\end{array}$ & $\begin{array}{l}\text { We printed inspiring quotations from local authors on signs across the City. } \\
\text { We also placed a phone number on each sign. If you called it, you would } \\
\text { hear the author reading their quote. }\end{array}$ & $\begin{array}{l}\text { To inspire residents of a neighborhood. To strengthen } \\
\text { the sense of community and neighborhood values. }\end{array}$ & $\mathrm{x}$ & $\mathrm{x}$ & $\mathrm{x}$ & & & & & \\
\hline $\begin{array}{l}\text { Twitter-tree } \\
\text { menorah }\end{array}$ & $\begin{array}{l}\text { PUB } 2 \\
\text { PRIV } 1\end{array}$ & $\begin{array}{l}\text { Our interactive tree and Menorah change color when people tweet a color } \\
\text { using the hashtag \#WickedCoolTree. }\end{array}$ & To create a more inviting atmosphere in City Hall. & $\mathrm{x}$ & $\mathrm{x}$ & $\mathrm{x}$ & & & & & \\
\hline City Hall to go truck & $\begin{array}{l}\text { PUB } 2 \\
\text { PRIV } 0\end{array}$ & $\begin{array}{l}\text { City Hall To Go Truck will visit Boston's neighborhoods through the year } \\
\text { and offer a select menu of City services directly to constituents. }\end{array}$ & To serve City residents. & & $\mathrm{x}$ & & & & & & $\mathrm{x}$ \\
\hline Pulse of the City & PUB 0PRIV 1 & $\begin{array}{l}\text { At public art installations, a heart-rate monitor in the shape of heart would } \\
\text { play music back to you in rhythm with your heartbeat. We placed five } \\
\text { installations at spots around the City of Boston. }\end{array}$ & $\begin{array}{l}\text { To use a fun piece of street furniture and technology to } \\
\text { advance a public health interest. }\end{array}$ & $x$ & $\mathrm{x}$ & & & $\mathrm{x}$ & & & \\
\hline $\begin{array}{l}\text { Participatory } \\
\text { Chinatown }\end{array}$ & $\begin{array}{l}\text { PUB } 1 \\
\text { PRIV } 3\end{array}$ & $\begin{array}{l}\text { A character-driven virtual world that allowed residents to explore } \\
\text { Chinatown. }\end{array}$ & $\begin{array}{l}\text { To allows users to consider issues from many } \\
\text { viewpoints. To engage more people. To lead to a more } \\
\text { balanced set of priorities for Chinatown's 10-year } \\
\text { Master Plan. }\end{array}$ & $x$ & $x$ & & & & & $x$ & \\
\hline Hub2 & $\begin{array}{l}\text { PUB } 1 \\
\text { PRIV } 1\end{array}$ & $\begin{array}{l}\text { Participants were given the chance to explore the proposed space from } \\
\text { multiple perspectives. They could also offer feedback on the design to } \\
\text { project planners and developers. }\end{array}$ & $\begin{array}{l}\text { To create constructive discussion between residents, } \\
\text { planners, and developers. }\end{array}$ & $x$ & $x$ & & & & & $x$ & \\
\hline
\end{tabular}

* Area of intervention: A (ICT); B (Social Relationships); C (Built Environment); D (Mobility); E (Health \& Safety); F (Business); G (Urban visioning\& Planning); H (Procedures \& Policies). 
Table A1. Cont.

(d)

\begin{tabular}{|c|c|c|c|c|c|c|c|c|c|c|c|}
\hline \multirow{2}{*}{ Project Name } & \multirow{2}{*}{$\begin{array}{l}\text { Partner } \\
\text { Type } \mathbf{n}^{\circ}\end{array}$} & \multirow{2}{*}{ Project Description } & \multirow{2}{*}{ Specific Objective } & \multicolumn{8}{|c|}{ Areas of Intervention * } \\
\hline & & & & A & B & C & $\mathbf{D}$ & $\mathrm{E}$ & $\mathbf{F}$ & G & $\mathbf{H}$ \\
\hline Boston Saves & $\begin{array}{l}\text { PUB } 3 \\
\text { PRIV } 0\end{array}$ & $\begin{array}{l}\text { Boston Saves gives each kindergartner an account with } \$ 50 \text { from the City } \\
\text { of Boston. The money in this account can be used for college or job } \\
\text { training costs after the student finishes high school. Families can earn } \\
\text { more from the City. }\end{array}$ & $\begin{array}{l}\text { To help families of Boston's district and charter } \\
\text { kindergartner (K2) students save for college or career } \\
\text { training. }\end{array}$ & $\mathrm{x}$ & & & & & & & $x$ \\
\hline Safeboard & $\begin{array}{l}\text { PUB } 1 \\
\text { PRIV } 0\end{array}$ & An experimental tap card system on Boston Public Schools (BPS) Buses. & $\begin{array}{l}\text { To explore new ways to engage parents about their } \\
\text { children's bus rides. To build stronger relationships } \\
\text { between families and the district. To allow the district to } \\
\text { make data-driven decisions about their service. }\end{array}$ & $\mathrm{x}$ & $\mathrm{x}$ & & $\mathrm{x}$ & & & & \\
\hline Discovery BPS & $\begin{array}{l}\text { PUB } 1 \\
\text { PRIV } 2\end{array}$ & $\begin{array}{l}\text { The website helps parents find which available schools might be the best } \\
\text { fit for their child. }\end{array}$ & $\begin{array}{c}\text { To make that school choosing decision process easier to } \\
\text { handle. }\end{array}$ & $x$ & $\mathrm{x}$ & & & & & & $\mathrm{x}$ \\
\hline $\begin{array}{l}\text { Where is my school } \\
\text { bus }\end{array}$ & $\begin{array}{l}\text { PUB } 1 \\
\text { PRIV } 2\end{array}$ & $\begin{array}{l}\text { Our program offers real-time tracking of school buses through a mobile } \\
\text { web app. }\end{array}$ & To track child's buses. & $\mathrm{x}$ & $\mathrm{x}$ & & & & & & \\
\hline Youth lead change & $\begin{array}{l}\text { PUB } 1 \\
\text { PRIV } 0\end{array}$ & $\begin{array}{l}\text { A participatory budgeting process where young Bostonian decide how to } \\
\text { spend } \$ 1,000,000 \text { of the City's budget. }\end{array}$ & To decide how to spend $\$ 1,000,000$ & & $\mathrm{x}$ & & & & & $\mathrm{x}$ & $x$ \\
\hline Lunch on the lawn & $\begin{array}{l}\text { PUB } 4 \\
\text { PRIV } 1\end{array}$ & We offered nutritious lunches to young people 18 and under. & $\begin{array}{l}\text { To make City Hall Plaza a welcoming space for all } \\
\text { Bostonians. }\end{array}$ & & $\mathrm{x}$ & & & $\mathrm{x}$ & & & $\mathrm{x}$ \\
\hline
\end{tabular}

* Area of intervention: A (ICT); B (Social Relationships); C (Built Environment); D (Mobility); E (Health \& Safety); F (Business); G (Urban visioning\& Planning); H (Procedures \& Policies).

(e)

\begin{tabular}{|c|c|c|c|c|c|c|c|c|c|c|c|}
\hline \multirow{2}{*}{ Project Name } & \multirow{2}{*}{$\begin{array}{l}\text { Partner } \\
\text { Type }^{\circ}\end{array}$} & \multirow{2}{*}{ Project Description } & \multirow{2}{*}{ Specific Objective } & \multicolumn{8}{|c|}{ Areas of Intervention * } \\
\hline & & & & A & B & $\mathrm{C}$ & D & $\mathrm{E}$ & $\mathbf{F}$ & G & $\mathrm{H}$ \\
\hline $\begin{array}{c}\text { Boston area } \\
\text { Research Initiative }\end{array}$ & PUB OPRIV 1 & $\begin{array}{l}\text { The initiative helped formalize partnerships with schools. This allowed us } \\
\text { to expand our research and share data. We also built relationships between } \\
\text { regions. }\end{array}$ & $\begin{array}{l}\text { To strengthen the ties between local universities and the } \\
\text { City. To spur original urban research that helped } \\
\text { schools and the City. }\end{array}$ & & $\mathrm{x}$ & & & & & $\mathrm{x}$ & $\mathrm{x}$ \\
\hline $\begin{array}{l}\text { Boston civic media } \\
\text { consortium }\end{array}$ & PUBPRIV 1 & Advancing civic media research, teaching, and practice in Boston. & $\begin{array}{l}\text { To enhance education at colleges and universities. To } \\
\text { build an active network of academic partners in the } \\
\text { Boston area. }\end{array}$ & & $\mathrm{x}$ & & & & & & $\mathrm{x}$ \\
\hline $\begin{array}{l}\text { Design action } \\
\text { research with } \\
\text { government }\end{array}$ & PUB OPRIV 1 & $\begin{array}{l}\text { Design Action Research with Government (DARG) is a guide for creating } \\
\text { civic innovation projects. }\end{array}$ & $\begin{array}{l}\text { To build productive and sustainable ways of working } \\
\text { together for: governments, research institutions, and } \\
\text { local community groups. }\end{array}$ & & & & & & & $\mathrm{x}$ & \\
\hline $\begin{array}{l}\text { New Urban } \\
\text { Mechanics Summer } \\
\text { fellowship }\end{array}$ & $\begin{array}{l}\text { PUB } 1 \\
\text { PRIV } 0\end{array}$ & $\begin{array}{l}\text { During this highly selective, eight-week program, summer fellows work as } \\
\text { a team, generating and implementing creative and thoughtful new policies } \\
\text { to benefit the City of Boston. }\end{array}$ & $\begin{array}{l}\text { Offer a job opportunity to people with a passion for } \\
\text { public services. }\end{array}$ & & & & & & & $\mathrm{x}$ & $\mathrm{x}$ \\
\hline
\end{tabular}

* Area of intervention: A (ICT); B (Social Relationships); C (Built Environment); D (Mobility); E (Health \& Safety); F (Business); G (Urban visioning\& Planning); H (Procedures $\&$ Policies). 


\section{References}

1. Hartley, J. Innovation in governance and public services: Past and present. Public Money Manag. 2005, 25, 27-34.

2. National Health Service Audit Commission. Seeing the Light: Innovation in Local Public Services; Audit Commission for Local Authorities, the National Health Service: London, UK, 2007.

3. Verhoest, K.; Verschuere, B.; Bouckaert, G. Pressure, legitimacy, and innovative behavior by public organizations. Governance 2007, 20, 469-497. [CrossRef]

4. Brown, K.; Osborne, S.P. Managing Change and Innovation in Public Service Organizations; Routledge: London, UK, 2012.

5. Osborne, S.P.; Brown, L. Introduction: Innovation in public services. In Handbook of Innovation in Public Services; Stephen, P.O., Brown, L., Eds.; Edward Elgar: Cheltenham, UK, 2013; pp. 1-11.

6. Sahni, N.R.; Wessel, M.; Christensen, C.M. Unleashing breakthrough innovation in government. Stanf. Soc. Innov. Rev. 2013, 11, 27-31.

7. Borins, S. The Persistence of Innovation in Government. A Guide for Innovative Public Servants; IBM Center for the Business of Government: Washington, DC, USA, 2014; Available online: http://www.businessofgovernment. org/sites/default/files/The\%20Persistence\%20of\%20Innovation\%20in\%20Government.pdf (accessed on 6 November 2018).

8. Borins, S. The Persistence of Innovation in Government; Brookings Institution Press with Ash Center for Democratic Governance and Innovation: Washington, DC, USA, 2014.

9. Bugge, M.M.; Bloch, C.W. Between bricolage and breakthroughs_Framing the many faces of public sector innovation. Public Money Manag. 2016, 36, 281-288. [CrossRef]

10. Raco, M. Competition, Collaboration and the New Industrial Districts: Examining the Institutional Turn in Local Economic Development. Urban Stud. 1999, 36, 951-968. [CrossRef]

11. Widestrom, A. Displacing Democracy: Economic Segregation in America; University of Pennsylvania Press: Philadelphia, PA, USA, 2015.

12. Iammarino, S.; Rodriguez-Pose, A.; Storper, M. Regional Inequality in Europe: Evidence, Theory and Policy Implications [PDF File]; Urban and Regional Research Center Utrecht University: Utrecht, The Netherlands, 2018; Available online: http://econ.geog.uu.nl/peeg/peeg.html (accessed on 10 July 2019).

13. Verschuere, B.; Brandsen, T.; Pestoff, V. Co-production: The State of the Art in Research and the Future Agenda. Volunt. Int. J. Volunt. Nonprofit Organ. 2012, 23, 1083-1101. [CrossRef]

14. Voorberg, W.H.; Bekkers, V.J.J.M.; Tummers, L.G. A Systematic Review of Co-Creation and Co-Production: Embarking on the social innovation journey. Public Manag. Rev. 2014, 17, 1333-1357. [CrossRef]

15. Arundel, A.; Casali, L.; Hollanders, H. How European public sector agencies innovate: The use of bottom-up, policy-dependent and knowledge-scanning innovation methods. Res. Policy 2015, 44, 1271-1282. [CrossRef]

16. De Vries, H.; Bekkers, V.; Tummers, L. Innovation in the public sector: A systematic review and future research agenda. Public Adm. 2016, 94, 146-166. [CrossRef]

17. Bason, C. Leading Public Sector Innovation: Co-Creating for a Better Society; Policy Press: Bristol, UK, 2017.

18. Moulaert, F.; Martinelli, F.; Swyngedouw, E.; Gonzalez, S. Towards Alternative Model(s) of Local Innovation. Urban Stud. 2005, 42, 1969-1990. [CrossRef]

19. Nicholls, A.; Murdock, A. Social Innovation: Blurring Boundaries to Reconfigure Markets; Palgrave Macmillan: Basingstoke, UK, 2012.

20. Nicholls, A.; Simon, J.; Gabriel, M. New Frontiers in Social Innovation Research; Palgrave Macmillan: London, UK, 2015.

21. Kazepov, Y. The territorial dimension of social policies and the new role of cities. In Handbook of European Social Policy; Kennett, P., Lendvai-Bainton, N., Eds.; Edward Elgar Publishing: Chelthenam, UK; Northampton, MA, USA, 2017.

22. Murray, R.; Calulier-Grice, J.; Mulgan, G. The Open Book of Social Innovation; National Endowment for Science, Technology and the Art: London, UK, 2010.

23. Brown, T. Design Thinking. Harv. Bus. Rev. 2008, 86, 84. Available online: https://readings.design/PDF/ Tim\%20Brown,\%20Design\%20Thinking.pdf (accessed on 29 September 2019). [PubMed]

24. Borins, S. Innovating with Integrity: How Local Heroes Are Transforming American Government; Georgetown University Press: Washington, DC, USA, 1998. 
25. Phills, A.; Deiglmeier, K.; Miller, D. Rediscovering Social Innovation. Stanf. Soc. Innov. Rev. 2008, 6, 34-43.

26. Bazurli, R.; Cucciniello, M.; Mele, V.; Nasi, G.; Valotti, G. Determinants and Barriers of Adoption, Diffusion and Upscaling of ICT-Driven Social Innovation in the Public Sector [PDF File]. In Proceedings of the EGPA Conference, Speyer, Germany, 10-12 September 2014; Available online: http://www.lipse.org/upload/ publications/Determinants\%20and\%20Barriers\%20of\%20Adoption\%20Diffusion\%20and.pdf (accessed on 8 October 2018).

27. Lemke, T. Foucault, governmentality, and critique. Rethink. Marx. 2002, 14, 49-64. [CrossRef]

28. Swyngedouw, E. Governance Innovation and the Citizen: The Janus Face of Governance-beyond-the-State. Urban Stud. 2005, 42, 1991-2006. [CrossRef]

29. Hajer, M. Policy without polity? Policy analysis and the institutional void. Policy Sci. 2003, 36, $175-195$. [CrossRef]

30. Hajer, M.A.; Wagenaar, H. Deliberative Policy Analysis: Understanding Governance in the Network Society; Cambridge University Press: Cambridge, MA, USA, 2003.

31. Jalonen, H. Clarifying 'fuzziness' in systemic welfare service innovation. In Proceedings of the 5th International Conference on Entrepreneurship, Innovation and Regional Development (ICEIRD), Sofia, Bulgaria, 1-2 June 2012; pp. 370-382.

32. Nonaka, I. A dynamic theory of organizational knowledge creation. Organ. Sci. 1994, 5, 14-37. [CrossRef]

33. Rogers, E.M. Diffusion of Innovations, 5th ed.; Free Press: New York, NY, USA, 2003.

34. Bevilacqua, C.; Pizzimenti, P. Living Lab and Cities as Smart Specialisation Strategies Engine. Procedia-Soc. Behav. Sci. 2016, 223, 915-922. [CrossRef]

35. Saad-Filho, A.; Johnston, D. Neoliberalism: A Critical Reader; Pluto Press: London, UK, 2005.

36. Jégou, F.; Bonneau, M. Social Innovation in Cities. URBACT II Capitalisation; URBACT Secretariat 5, rue Pleyel 93283 Saint Denis Cedex: Paris, France, 2015.

37. Vandecasteele, I.; Baranzelli, C.; Siragusa, A.; Aurambout, J.P.; Alberti, V.; Alonso Raposo, M.; Attardo, C.; Auteri, D.; Barranco, R.; Batista e Silva, F.; et al. The Future of Cities-Opportunities, Challenges and the Way Forward; EUR 29752 EN; Publications Office: Luxembourg, 2019; ISBN 978-92-76-03847-4. JRC116711. [CrossRef]

38. Heilbroner, R.; Milberg, W. The Crisis of Vision in Modern Economic Thought; Cambridge University Press: New York, NY, USA, 1995.

39. Chomsky, N. Understanding the Crisis. Markets, the State and Hypocrisy; Foreign Policy in Focus: Washington, DC, USA, 2009; Available online: https://chomsky.info/20090210/ (accessed on 1 November 2018).

40. Harvey, D. A Brief History of Neoliberalism; Oxford University Press: New York, NY, USA, 2005.

41. Harvey, D. From Managerialism to Entrepreneurialism: The Transformation in Urban Governance in Late Capitalism. Geogr. Ann. Ser. B Hum. Geogr. 1989, 71, 3-17. [CrossRef]

42. Parkinson, M. The rise of the entrepreneurial European city: Strategic responses to economic changes in the 1980s. Ekistics 1991, 58, 299-307.

43. Jensen-Butler, C.N.; Shachar, A.; Van Weesep, J. European Cities in Competition; Avebury: Aldershot, UK, 1996.

44. Saez Vegas, L.; Periáñez Cañadillas, I. Market Orientation in Local Government through the Analysis of Municipal Website Content: A Framework for its Measurement. Glob. J. Bus. Res. 2013, 7, 47-58.

45. Organization for Economic Co-operation and Development. Fostering Innovation to Address Social Challenges; Workshop proceedings [PDF File]; OECD: Paris, France, 2011; Available online: https://www.oecd.org/sti/ inno/47861327.pdf (accessed on 6 September 2018).

46. Gupta, A.K.; Sinha, R.; Koradia, D.; Patel, R.; Parmar, M.; Rohit, P.; Patel, H.; Patel, K.; Chand, V.S.; James, T.J.; et al. Mobilizing grassroots' technological innovations and traditional knowledge, values and institutions: Articulating social and ethical capital. Futures 2003, 35, 975-987. [CrossRef]

47. Seyfang, G.; Smith, A. Grassroots innovations for sustainable development: Towards a new research and policy agenda. Environ. Polit. 2007, 16, 584-603. [CrossRef]

48. Smith, A.; Fressoli, M.; Abrol, D.; Around, E.; Ely, A. Grassroots Innovation Movements; Routledge: New York, NY, USA, 2017.

49. Fressoli, M.; Arond, E.; Abrol, D.; Smith, A.; Ely, A.; Dias, R. When grassroots innovation movements encounter mainstream institutions: Implications for models of inclusive innovation. Innov. Dev. 2014, 4, 277-292. [CrossRef] 
50. Brandsen, T.; Cattacin, S.; Evers, A.; Zimmer, A. Social Innovations in the Urban Context; Springer: Cham, Switzerland, 2016.

51. MacCallum, D.; Moulaert, F.; Hillier, J.; Haddock, S.V. Social Innovation and Territorial Development; Ashgate: Aldershot, UK, 2009.

52. Moulaert, F. The International Handbook on Social Innovation: Collective Action, Social Learning and Transdisciplinary Research, Paperback, Reprinted eds.; Edward Elgar: Cheltenham, UK, 2015.

53. Westley, F.; Zimmerman, B.; Quinn Patton, M. Getting to Maybe: How the World Is Changed; Random House: Toronto, CA, USA, 2006.

54. Mulgan, G.; Tucker, S.; Ali, R.; Sanders, B. Social Innovation: What It Is, Why It Matters and How It can Be Accelerated; Skoll Centre for Social Entrepreneurship: Oxford, UK, 2007.

55. European Commission. This Is European Social Innovation. Retrieved September 2017. 2010. Available online: http://ec.europa.eu/DocsRoom/documents/19042 (accessed on 22 November 2018).

56. Terstriep, J.; Totterdill, P. Economic Foundation of Social Innovation-New Ways of Policy Production. In Proceedings of the RIP 2014 9th Regional Innovation Policy Conference, Stavanger, Norway, 16-17 October 2014; University of Stavanger: Stavanger, Norway, 2014.

57. Moore, M. Creating Public Value. Strategic Management in Government; Harvard University Press: Cambridge MA, USA, 1995.

58. Bekkers, V.; Tummers, L.G.; Stuijfzand, B.G.; Voorberg, W. Social Innovation in the Public Sector: An Integrative Framework; LIPSE Working papers (no. 1); Erasmus University Rotterdam: Rotterdam, The Netherlands, 2013.

59. March, J.G.; Olsen, J.P. Rediscovering Institutions: The Organizational Basis of Politics; Fee Press: New York, NY, USA, 1989.

60. Vigoda-Gadot, E.; Shoham, A.; Schwabsky, N.; Ruvio, A. Public sector innovation for Europe: A multinational eight-country exploration of citizens' perspectives. Public Adm. 2008, 86, 307-329. [CrossRef]

61. Nobbs, C.L. Economics, Sustainability, and Democracy: Economics in the Era of Climate Change; Routledge: Abingdon, Oxon; New York, NY, USA, 2013.

62. Porter, M.E. The Competitive Advantage of the Inner City. Harv. Bus. Rev. 1995, 73, 55-71.

63. Baltazar Herrera, M.E. Creating Competitive Advantage by Institutionalizing Corporate Social Innovation. J. Bus. Res. 2015, 68, 1468-1474. [CrossRef]

64. Kania, J.; Kramer, M. Collective Impact. In Stanford Social Innovation Review; Winter: Berlin/Heidelberg, Germany, 2011; pp. 36-41.

65. Bevilacqua, C.; Ou, Y. Place, Relationships, and Community-Controlled Capital: On Ecosystem-Based Innovation towards an Equitable Competitive Advantages Distribution, the Boston Ujima Project Case. Int. J. Sustain. Dev. Plan. 2018, 13, 1072-1089. [CrossRef]

66. Bloomberg. Here Are the Most Innovative States in America. 2016. Available online: https://www.bloomberg. com/news/articles/2016-01-07/here-are-the-most-innovative-states-in-america (accessed on 16 October 2018).

67. Harrison, J.D.; Gorman, S. Innovation that matters [PDF File]; US Chamber Foundation: Washington, DC, USA, 2017; Available online: https://www.uschamberfoundation.org/sites/default/files/media-uploads/ITM\% 202017.pdf (accessed on 20 October 2018).

68. City of Boston. New Urban Mechanics Department. 2017. Available online: www.boston.gov/departments/ new-urban-mechanics (accessed on 17 October 2018).

69. The URBAN Vision [Video File]; Boston's Mayor's Office of New Urban Mechanics: Boston, MA, USA, 2013; Available online: https://www.youtube.com/watch?v=-LyaivtnCmg (accessed on 17 October 2018).

70. City of Boston. New Urban Mechanics Summer Fellows [Video File]. 19 December 2014. Available online: https://www.youtube.com/watch?v=rNL03-CJv7o (accessed on 20 October 2018).

71. TM Forum. Nigel Jacob, Co-Chair, Mayor's Office of New Urban Mechanics, City of Boston [Video File]. 7-9 September 2016. Available online: https://vimeo.com/182986435 (accessed on 26 October 2018).

72. School of Public Policy and Urban Affairs-Northeastern University. Innovative Uses of Data for Managing Boston Today, and in 2030-Myra Kraft Open Classroom [Video File]. 29 November 2017. Available online: https://www.youtube.com/watch?v=oNrLvP2zWR4\&t=1493s (accessed on 28 October 2018).

73. Jacob, N. NIGEL JACOB: From the Smart City to the Learning City (Unknown, Interviewer). 15 September 2013. Available online: http://lombardia.forumpa.it/en/news/nigel-jacob-smart-city-learning-city (accessed on 8 September 2018). 
74. Borins, S. The Challenge of Innovating in Government [PDF File]; IBM Center for The Business of Government: Washington, DC, USA, 2016; Available online: http:/www.businessofgovernment.org/sites/default/files/ BorinsInnovatingInGov.pdf (accessed on 12 November 2018).

75. MONUM-Mayor's Office of New Urban Mechanics. Civic Research Agenda [PDF File]. 2018. Available online: https://www.boston.gov/departments/new-urban-mechanics/civic-research-agenda (accessed on 20 November 2018).

76. MONUM-Mayor's Office of New Urban Mechanics. New Urban Mechanics Year in Review [PDF File]. 2018. Available online: https://www.boston.gov/sites/default/files/document-file-02-2018/monum_yearinreview_ 2017_finalv2.pdf (accessed on 22 November 2018).

77. Bertalanffy, L. General System Theory: Foundations, Development, Applications, 18th ed.; Braziller: New York, NY, USA, 2015.

78. Capra, F.; Luisi, P.L. The Systems View of Life: A Unifying Vision, 6th ed.; Cambridge University Press: Cambridge, UK, 2016.

79. Capra, F. The Web of Life; Flamingo: London, UK, 1996.

80. Cole, R.L. Citizen Participation and the Urban Policy Process; Lexington Books: Lexington, KY, USA, 1974.

81. Raco, M.; Imrie, R. Governmentality and Rights and Responsibilities in Urban Policy. Environ. Plan. Econ. Space 2000, 32, 2187-2220. [CrossRef]

82. City of Copenhagen. Available online: https://innovationshuset.kk.dk (accessed on 10 January 2019).

83. City of Cluj-Napoca, Centrul Cultural Clujean. Available online: http://www.ccluj.ro (accessed on 6 December 2018).

84. Badger, E. The Dawn of the Municipal Chief Innovation Officer. 19 May 2012. Available online: https://www. citylab.com/solutions/2012/03/dawn-municipal-chief-innovation-officer/1516/ (accessed on 18 October 2018).

85. Chesbrough, H. The era of open innovation. MIT Sloan Manag. Rev. 2003, 44, 35-41.

86. Chesbrough, H. Open Innovation. A New Paradigm for Understanding Industrial Innovation. In Open Innovation. Researching a New Paradigm; Chesbrough, H., Vanhaverbeke, W., West, J., Eds.; Oxford University Press: Oxford, UK, 2006.

87. Von Hippel, E. The dominant role of users in the scientific instrument innovation process. Res. Policy 1976, 5, 212-239. [CrossRef]

88. Von Hippel, E. Democratizing Innovation; MIT Press: Cambridge, MA, USA, 2005.

89. Von Hippel, E. Horizontal innovation networks-By and for users. Ind. Corp. Chang. 2007, 16, $293-315$. [CrossRef]

90. Bekkers, V.; Edelenbos, J.; Steijn, A.J. Linking innovation to the public sector: Contexts, concepts and challenges. In Innovation in the Public Sector: Linking Capacity and Leadership; Bekkers, V., Edelenbos, J., Steijn, A.J., Eds.; Palgrave Macmillan: Basingstoke, UK, 2014; pp. 3-34.

91. Bekkers, V.; Fenger, M.; Scholten, P. Public Policy in Action: Perspectives on the Policy Process; Edward Elgar Publishing: Cheltenham, UK, 2017.

92. Mayer, M. Manuel Castells' the city and the grassroots. Int. J. Urban Reg. Res. 2006, 30, 202-206. [CrossRef]

93. Chorianopoulos, I.; Tselepi, N. Austerity governance and bifurcated civil society: The changing matrices of urban politics in Athens. J. Urban Aff. 2019. [CrossRef]

94. Stickdorn, M.; Schneider, J. This Is Service Design Thinking: Basics, Tools, Cases, 6th ed.; BIS: Amsterdam, The Netherlands, 2016.

95. Leifer, L.; Meinel, C.; Plattner, H. Design Thinking Research: Making Design Thinking Foundational; Springer International Publishing: Cham, Switzerland, 2016.

(C) 2019 by the authors. Licensee MDPI, Basel, Switzerland. This article is an open access article distributed under the terms and conditions of the Creative Commons Attribution (CC BY) license (http://creativecommons.org/licenses/by/4.0/). 